\title{
Effects of Extended Grape Ripening With or Without Must and Wine Alcohol Manipulations on Cabernet Sauvignon Wine Sensory Characteristics
}

H. Heymann ${ }^{1 *}$, M. LiCalzi ${ }^{2}$, M.R. Conversano ${ }^{3}$, A. Bauer ${ }^{4}$, K. Skogerson ${ }^{5}$, M. Matthews ${ }^{6}$

(1) Department of Viticulture \& Enology, University of California, 1136 RMI North, 595 Hilgard Lane, Davis, CA 95616-5270, USA

(2) 150 rue Isaac Newton 13100 Aix-en-Provence, France

(3) Bell Wine Cellars, 6200 Washington Street, Yountville, CA 94599, USA

(4) Hamburg University of Applied Sciences, Faculty Life Sciences, Department Food Science and Nutrition, Lohbruegger Kirchstr. 65, 21033 Hamburg, Germany

(5) Monsanto Center for Food and Nutrition, 150 N. Research Campus Drive, Suite 3700, Kannapolis, NC 28081, USA

(6) Department of Viticulture \& Enology, University of California, 1136 RMI North, 595 Hilgard Lane, Davis, CA 95616-5270, USA

Submitted for publication: November 2012

Accepted for publication: February 2013

Key words: Extended ripening, grape maturity, sensory descriptive analysis, wine alcohol manipulations

The research was conducted by the above authors while they were affiliated with the Department of Viticulture and Enology at the University of California, Davis, USA

\begin{abstract}
This study attempts to clarify the consequences for wine flavour that result from harvesting fruit at different maturities. The grapes were harvested from a single vineyard in Paso Robles, and the samples spanned maturity levels from what would be considered early harvest (about $21^{\circ} \mathrm{Brix}$ ) to late harvest (about $30^{\circ} \mathrm{Brix}$ ). The wines made from these grapes were analysed using descriptive analysis to investigate the relationships between fruit maturity and wine sensory attributes. In addition, musts and/or wines were chaptalised and/or fortified or watered back to determine the effect of these manipulations on wine sensory properties. This research showed that the sensory attributes of wines made from grapes at different stages of maturation, from about 20 to $30{ }^{\circ}$ Brix, varied in a systematic fashion. Specifically, the wines made from the grapes with a lower Brix were more sour and had more fresh vegetative flavours, while the wines made from the fruit with a high Brix were more hot and bitter and in some cases had more dark fruit flavours and sweetness. Fortifying wines made from lower Brix musts changed the perceptions of the wine sensory profiles more than chaptalising the musts. On the other hand, adding water to higher ${ }^{\circ}$ Brix musts to mimic $24{ }^{\circ}$ Brix musts resulted in wines with similar sensory profiles to wines made from grapes picked at a sugar content of close to $24^{\circ}$ Brix. This study shows that wine sensory attributes differ more when grapes are picked early in ripening rather than after $24^{\circ}$ Brix.
\end{abstract}

\section{INTRODUCTION}

The concentration of sugars increases in ripening fruit, and grapes are no exception. The sugar concentration (measured as ${ }^{\circ}$ Brix in this study) has been a common objective parameter of fruit maturity in viticulture. Although some earlier studies suggest that sugar/acid ratios are superior metrics for wine grape maturity (e.g. Du Plessis \& Van Rooyen, 1982), for at least 50 years the recommended maturity for harvesting wine grapes in California was 20 to $23^{\circ}$ Brix (Amerine, 1953), or 21 to $24{ }^{\circ}$ Brix (Cooke, 1969). Commercial practice has, of course, used a very wide range of fruit maturities over the centuries, from very low concentrations that require sugar additions ('chaptalisation') in order to obtain a legal wine (one with at least $7 \%$ alcohol), to the recent and controversial long "hang time" phenomenon in California (Hirsch, 2005), in which grapes are harvested at a high ${ }^{\circ}$ Brix of 28 or more. However, there appear to have been no comprehensive studies guiding the early recommendations or the recent move to later harvesting. Indeed, the literature on the effect of extended fruit maturation on wine composition and

*Corresponding author: E-mail: hheymann@ucdavis.edu

Aknowledgements: We thank Jerry Lohr and Lohr Vineyards and Wines, for the generous donation of the grapes, as well as for the use of their experimental winery to ferment the wines. The research was generously funded by the American Vineyard Foundation. We also thank Jean Dodson, Meghan Daniels Rech and Kevin Scott, for technical assistance 
sensory attributes is sparse and often inconsistent.

Where advanced fruit maturity has been evaluated, the concentration of anthocyanins peaked at $25{ }^{\circ}$ Brix (Holt et al., 2010) or continued to increase (Torchio et al., 2010) in Cabernet Sauvignon and Barbera grapes respectively. The concentration of grape tannins continued to increase above $25{ }^{\circ}$ Brix (Holt et al., 2011), or was generally stable or decreased after $25^{\circ}$ Brix (Torchio et al., 2010). Similarly for norisoprenoids, for example, $\beta$-damascenone was reported to increase up to $30^{\circ}$ Brix (Fang \& Qian, 2006), but did not increase significantly throughout fruit ripening in other studies (Marais et al., 1992; Ristic et al., 2007). There are a number of publications on the effects of extended grape maturation or high values of soluble solids on grape composition, especially on the effect on phenolics (Holt et al., 2010; Obreque-Slier et al., 2010; Torchio et al., 2010; Rolle et al., 2011).

Fang and Qian (2006) evaluated Pinot noir wines made from grapes harvested at between 21 and $33{ }^{\circ}$ Brix and found that esters, with the exception of the short chain fattyacid esters, decreased with increased grape maturity, while guaiacols, $\mathrm{C}_{13}$ norisoprenoids and monoterpenes increased. Moreno et al. (2008) did not harvest grapes at high ${ }^{\circ}$ Brix, but picked Pinot noir at 22 and $24^{\circ}$ Brix and then dehydrated a subset of these grapes to 24.8 and $26.7^{\circ}$ Brix respectively. They found that wines made from dehydrated grapes had increased monoterpenes and guaiacols, as well as increased $\mathrm{C}_{13}$ norisoprenoids, and that changes in aroma compound concentrations due to dehydration were similar to the changes in concentration found with extended ripening on the vine. However, neither of these two studies conducted any sensory evaluation on the resulting wines.

Chaney et al. (2006) harvested Chardonnay and Shiraz at about $26^{\circ} \mathrm{Brix}$ and $30^{\circ} \mathrm{Brix}$ respectively, and then diluted some of the musts back to $24^{\circ} \mathrm{Brix}$ and $22^{\circ}$ Brix respectively. After fermentation, the wines were equalised in alcohol concentration by the addition of deodorised ethanol. Triangle tests performed by a 24-member panel indicated that the Chardonnay wines made from the diluted musts (with added ethanol after fermentation) were not significantly different from the Chardonnay wines made from the original, must but that the Shiraz wines did differ.

Descriptive analysis transcends quality and difference measurements by determining sensory attributes that differ among wines without reliance on the preferences of judges (Lawless \& Heymann, 2010). A few studies have used descriptive analysis to characterise the impact of viticultural practices (e.g. Chapman et al., 2004a, b; Cortell et al., 2008). Many of the studies that report on the sensory properties of wines made from fruit of different maturities were conducted at ${ }^{\circ}$ Brix less than 23 (e.g. Callao et al., 1991), or with varieties that are not generally sought after for fine wine production, such as Vidal blanc and Thompson Seedless (e.g. Gallander, 1983; Suresh \& Ethiraj, 1987; Chikkasubbanna et al., 1990; Sharma et al., 1997). Studies that evaluated more commonly used varieties include Marais et al. (1987), who showed that Gewürztraminer wine fruitiness and quality were significantly greater when grapes were harvested at 23 than $22{ }^{\circ}$ Brix. Wine quality scores increased for about a dozen red varieties, including Cabernet Sauvignon, for wines made from grapes harvested between 24 and $25^{\circ}$ Brix compared to between 21 and $22^{\circ}$ Brix (Berg \& Ough, 1977).

Therefore, a comprehensive study of wines made from grapes of various maturities extending late into ripening was designed and executed. The aims of this study were to use descriptive analysis to answer the following questions pertaining to fruit maturity and wine sensory attributes:

1. Which sensory attributes of wines change in a detectable and reproducible manner as the fruit maturity increases? To answer this question we compared wines made from fruits harvested over a range of approximately $10^{\circ} \mathrm{Brix}$.

2. Can differences in wines made from grapes harvested at different maturity levels be attributed to differences in alcohol concentration? To answer this question we added sugar to must with a low ${ }^{\circ}$ Brix (less than $24^{\circ} \mathrm{Brix}$ ) or water to must with a high ${ }^{\circ} \mathrm{Brix}$ (more than $24{ }^{\circ}$ Brix) to bring the musts to $24{ }^{\circ} \mathrm{Brix}$; in addition, a subset of finished wines from low ${ }^{\circ}$ Brix fruit was fortified to the alcohol concentration present in wines made from fruit with a higher ${ }^{\circ}$ Brix $\left(24^{\circ}\right.$ Brix $)$. We also watered back a subset of finished wines made from higher ${ }^{\circ}$ Brix fruit to the alcohol concentration present in wines made from fruit at $24^{\circ} \mathrm{Brix}$.

\section{MATERIALS AND METHODS}

Cabernet Sauvignon grapes were harvested at six maturities (based on ${ }^{\circ}$ Brix; harvests are coded H1 through H6) during three consecutive vintages. Each harvest was planned to be approximately $2{ }^{\circ}$ Brix apart (exact maturities, dates and timing were dependent on the ripening pattern of the specific harvest; see Table 1). Wines were made from the grapes as harvested (these wines are coded either by the ${ }^{\circ}$ Brix level of the grapes at harvest, or they are coded NN for No prior and No post-fermentation additions). In addition, must from fruit harvested above $24{ }^{\circ} \mathrm{Brix}$ was diluted to $24{ }^{\circ} \mathrm{Brix}$ prior to fermentation (coded as BN for additions Before fermentation but Not post-fermentation), and must from fruit harvested below $24^{\circ}$ Brix was chaptalised to $24^{\circ}$ Brix (also coded as BN for additions Before fermentation but Not post-fermentation) (Table 2). Finished wines made from fruit harvested at less than $24{ }^{\circ}$ Brix were fortified to alcohol levels similar to what would be present in wines made from fruit at $24{ }^{\circ} \mathrm{Brix}$ (coded as either NA for No additions prior to fermentation

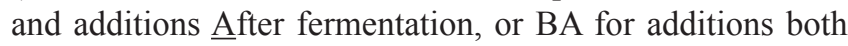
$\underline{B}$ fore and $\underline{A}$ fter fermentation). Finished wines made from fruit harvested above $24^{\circ}$ Brix were diluted back to alcohol concentrations similar to that present in wines made from fruit at $24{ }^{\circ}$ Brix (coded as either NA for No additions prior to fermentation and additions, and $\underline{A}$ fter fermentation, or BA for additions both $\underline{B}$ efore and $\underline{A}$ fter fermentation) (Table 2). It should be clear from the harvest number (H1 through H6 and Table 1) whether a specific wine had been fortified or watered down after fermentation.

\section{Harvest}

Fruit were harvested from a commercial vineyard of Cabernet Sauvignon grapevines (Vitis vinifera L.), clone 8 on 1103P rootstock, near Paso Robles, California, planted with a 7' $\mathrm{x}$ $8^{\prime}(2.1 \times 2.4 \mathrm{~m})$ spacing and trained to a bilateral cordon. The 
TABLE 1

Harvest data for 2006, 2007 and 2008 Central Coast Cabernet Sauvignon grapes harvested at a range of maturity levels. (Days post-véraison in parentheses).

\begin{tabular}{llcccccccc}
\hline $\begin{array}{l}\text { Harvest } \\
\text { (desired Brix) }\end{array}$ & \multicolumn{2}{c}{ 2006: Véraison 8/9/06 } & \multicolumn{3}{c}{ 2007: Véraison 8/1/07 } & \multicolumn{3}{c}{ 2008: Véraison 8/16/08 } \\
\cline { 2 - 10 } & Date & Brix & $\begin{array}{c}\text { Yield } \\
\text { (ton/a) }\end{array}$ & Date & Brix & $\begin{array}{c}\text { Yield } \\
\text { (ton/a) }\end{array}$ & Date & $\begin{array}{c}\text { Yield } \\
\text { Brix } \\
\text { (ton/a) }\end{array}$ \\
\hline H1 (20) & $9 / 6$ & $22.4(29)$ & 4.1 & $8 / 23$ & $21.0(23)$ & 4.3 & $8 / 27$ & $19.9(21)^{2}$ & $2.5^{1}$ \\
H2 (22) & $9 / 15$ & $23.1(38)$ & 4.0 & $8 / 30$ & $22.1(30)$ & 4.9 & $9 / 4$ & $22.6(29)$ & 2.7 \\
H3 (24) & $9 / 30$ & $24.7(53)$ & 4.2 & $9 / 7$ & $24.6(38)$ & 4.3 & $9 / 16$ & $23.2(41)$ & 2.7 \\
H4 (26) & $10 / 21$ & $26.0(74)$ & 4.1 & $9 / 27$ & $26.2(58)$ & 4.5 & $10 / 8$ & $25.0(63)$ & 3.1 \\
H5 (28) & $11 / 4$ & $27.8(88)$ & NA & $10 / 19$ & $26.2(80)$ & 4.7 & $10 / 16$ & $36.6(84)$ & 2.1 \\
H6 (30) & $11 / 15$ & $30.7(98)$ & NA & $11 / 28$ & $30.8(120)$ & 3.3 & & & \\
\hline
\end{tabular}

${ }^{1}$ On 2008-05-21, a "moderately out of range" wind, reported by the weather station in Atascadero (average speed was $7 \mathrm{miles} / \mathrm{hr}$ ), occurred three days after flowering. This caused a marked shattering of the blooming clusters in our experimental vineyard, as well as in the greater Paso Robles area. This meteorological event mimicked an "early green drop" practised by some viticulturists. This resulted in a 37 to 39\% lower crop yield in 2008 compared to the previous vintages.

${ }^{2}$ Due to a bacterial infection during winemaking, these wines were not evaluated by sensory descriptive analysis.

${ }^{3}$ A severe frost on 2008-09-11, between the dates of harvest 4 and 5, damaged the vines to such an extent that the fruit desiccated and the harvest 5 fruit were picked at $36.6^{\circ}$ Brix. We decided not to attempt a sixth harvest. The must from this harvest was watered back to $30{ }^{\circ}$ Brix prior to fermentation and thus the $\mathrm{H} 5 \mathrm{NN}$ for this year is based on $30{ }^{\circ} \mathrm{Brix}$.

TABLE 2

Treatment summary of musts harvested below $24^{\circ}$ Brix and above $24^{\circ}$ Brix.

\begin{tabular}{|c|c|c|c|c|c|c|c|c|}
\hline Degrees Brix at & & Belo & W $24^{\circ}$ Brix & & & $\mathrm{Abc}$ & e $24^{\circ}$ Brix & \\
\hline $\begin{array}{l}\text { Treatment before } \\
\text { fermentation }\end{array}$ & None & None & $\begin{array}{l}\text { Add sugar } \\
\text { to } 24^{\circ} \text { Brix }\end{array}$ & $\begin{array}{l}\text { Add sugar } \\
\text { to } 24^{\circ} \text { Brix }\end{array}$ & None & None & $\begin{array}{l}\text { Add water } \\
\text { to } 24^{\circ} \text { Brix }\end{array}$ & $\begin{array}{l}\text { Add water } \\
\text { to } 24^{\circ} \text { Brix }\end{array}$ \\
\hline $\begin{array}{l}\text { Treatment after } \\
\text { fermentation }\end{array}$ & None & $\begin{array}{l}\text { Add ethanol to } \\
\text { equal } 24^{\circ} \text { Brix } \\
\text { wine }\end{array}$ & None & $\begin{array}{l}\text { Add ethanol to } \\
\text { equal } 24^{\circ} \text { Brix } \\
\text { wine }\end{array}$ & None & $\begin{array}{l}\text { Add water to } \\
\text { equal } 24^{\circ} \text { Brix } \\
\text { wine }\end{array}$ & None & $\begin{array}{l}\text { Add water to } \\
\text { equal } 24^{\circ} \text { Brix } \\
\text { wine }\end{array}$ \\
\hline Treatment code & $\mathrm{NN}$ & NA & $\mathrm{BN}$ & BA & $\mathrm{NN}$ & NA & $\mathrm{BN}$ & BA \\
\hline
\end{tabular}

vines had a winter pruning regime of 40 to 50 buds per vine. Fruit were harvested by hand and immediately brought to the adjacent winery near Paso Robles, CA, on the day of harvest.

A severe frost on 2008-10-11, between harvest 4 (H4) and 5 (H5), damaged the vines to such an extent that the fruit desiccated and the $\mathrm{H} 5$ fruit were picked at $36.6^{\circ} \mathrm{Brix}$; this must was watered back to $30^{\circ}$ Brix prior to fermentation. We decided not to attempt a sixth harvest. In addition, the wines from the harvest 1 (H1) date in 2008 were contaminated by Bacillus megaterium and an unidentified Lactobacillus, and we chose not to do chemical or sensory evaluation of these wines.

\section{Winemaking}

Wines were made in triplicate in $450 \mathrm{~kg}$ lots at all six maturities (except H6 in 2008). Fruit were crushed the day after harvest. A standard winemaking protocol was used, which included the following: a $500 \mathrm{ml}$ sample was taken from each bin for $\mathrm{pH}$, titratable acidity (TA), ${ }^{\circ} \mathrm{Brix}$, fresh berry mass, yeast assimilable nitrogen (YAN) and grape phenolics (data not shown). Fruit were crushed in a crusher/ destemmer. After crushing, the acidity was adjusted to $7 \mathrm{~g} / \mathrm{L}$ and $30 \mathrm{ppm} \mathrm{SO}_{2}$ was added. Yeast (LALVIN-ICV-D254 from Scott Laboratories, Petaluma CA) was added to the must with a $300 \mathrm{ppm}$ addition of Fermaid K (Lallemand, Montreal, Canada) if the Brix was over 26. Di-ammonium phosphate (Scott Laboratories, Petaluma, CA) was added the next day to a level of $150 \mathrm{mg} / \mathrm{L}$. Thrice-daily five-minute punch downs were performed for six days. On day seven the wines were pressed and drained into a new bin. The wine was allowed to settle and then the wines were racked into four 15 gal (56 L) glass carboy for each fermentation replicate of each treatment. A malolactic culture (LALVIN Bacchus, Scott Laboratories, Petaluma, CA) was added, using the concentration specified by the supplier. Post-malolactic fermentation the $\mathrm{SO}_{2}$ was adjusted to $30 \mathrm{ppm}$ free $\mathrm{SO}_{2}$. Three months later the wines were racked and bottled in $750 \mathrm{~mL}$ glass bottles with screw caps, with the $\mathrm{SO}_{2}$ adjusted to 30 ppm free $\mathrm{SO}_{2}$ if necessary. Wines were made in triplicate for each harvest date. The $2008 \mathrm{H} 5$ must was watered back from $36.6{ }^{\circ}$ Brix to $30^{\circ}$ Brix prior to yeast inoculation, thus the base sugar content for the wines of this harvest was $30^{\circ}$ Brix.

In addition, the lower ${ }^{\circ}$ Brix juices were chaptalised with sugar ( $\mathrm{C} \& \mathrm{H}$ pure cane sugar, San Francisco, CA), and the higher ${ }^{\circ}$ Brix juices were watered down prior to fermentation to mimic wines made from grapes at $24{ }^{\circ}$ Brix. During bottling, a portion of the wine made from the lower ${ }^{\circ} \mathrm{Brix}$ grapes was fortified with alcohol (151 Proof EverClear, Luxco, St Louis, MO), and wines made from grapes with a higher ${ }^{\circ}$ Brix were watered to mimic wines made from grapes at $24{ }^{\circ}$ Brix. 
TABLE 3

Sensory descriptors and reference standards used in the descriptive analyses of the 2006, 2007 and 2008 wines.

\begin{tabular}{|c|c|}
\hline Attribute & Standard \\
\hline Red fruit & $\begin{array}{l}1 \text { small frozen strawberry, thawed and crushed (Trader Joe's Organic Strawberries, } 6.5 \mathrm{~g} \text { ) }+1 \text { tsp raspberry jam (World } \\
\text { Market, } 6 \mathrm{~g} \text { ) }\end{array}$ \\
\hline Dark fruit & $\begin{array}{l}1 \text { frozen dark cherry, thawed and crushed (Trader Joe's Dark Sweet Cherries, } 6 \mathrm{~g})+1 \text { frozen blackberry, thawed and crushed } \\
\text { (Trader Joe's Frozen Blackberries, } 6 \mathrm{~g} \text { ) }+1 \text { tsp blackcurrant jam (Hero, } 7 \mathrm{~g})+1 \text { tsp blackberry spread (Smuckers Simply } \\
100 \% \text { Fruit Seedless Blackberry, } 5 \mathrm{~g} \text { ) }\end{array}$ \\
\hline Dried fruit & 1 small prune cut in half (Sunsweet Gold Label Pitted Prunes, $6 \mathrm{~g}$ ) +5 raisins cut in half (SunMaid Raisins, $2.5 \mathrm{~g}$ ) \\
\hline Fresh veg & freshly cut grass clippings $(1 \mathrm{~g})+$ green pepper slice $(0.15-0.17 \mathrm{~g})$ \\
\hline Cooked veg & canned asparagus + brine (Albertson's salt free, $5 \mathrm{~g}$ ) + canned green beans + brine (Albertson's salt-free, $4 \mathrm{~g}$ ) \\
\hline Dried veg & dry hay $(0.5 \mathrm{~g})+$ tea (Lipton, $30 \mathrm{mg})+$ dried basil (Trader Joe's, $5 \mathrm{mg})$ \\
\hline Spicy & ground black pepper ( $5^{\text {th }}$ Season, $20 \mathrm{mg}$ ) + fennel seed, crushed (Schilling, $5 \mathrm{mg}$ ) \\
\hline Sweet taste & $20 \mathrm{~g}$ sucrose / $500 \mathrm{~mL}$ water \\
\hline Sour taste & $200 \mathrm{mg}$ citric acid / $500 \mathrm{~mL}$ water \\
\hline Bitter taste & $800 \mathrm{mg}$ caffeine / $500 \mathrm{~mL}$ water \\
\hline Astringent & $312 \mathrm{mg}$ alum / $500 \mathrm{~mL}$ water \\
\hline Hot & $25 \mathrm{~mL} 100 \%$ ethanol / $475 \mathrm{~mL}$ water \\
\hline Viscosity & $2.5 \mathrm{~g}$ pectin $/ 500 \mathrm{~mL}$ water \\
\hline
\end{tabular}

Unless otherwise indicated, all references were made up in $30 \mathrm{ml}$ wine base. Wine base was Franzia Vintner's Select Cabernet Sauvignon bag-in-the-box wine.

\section{Wine chemical analyses}

Ethanol was measured using an Anton Paar Alcolyzer (Graz, Austria). TA and $\mathrm{pH}$ were determined using autotritation (Mettler Toledo DL50 autotitrator and 60 Auto sampler with LABX software, Columbus, Ohio). Reducing sugars (RS) in the wines were measured using an enzymatic kit and a spectrophotometer [Infinity Glucose Hexokinase Reagent kit (ThermoDMA, Professional Lab Sales, Northridge, CA) and Phosphoglucoisomerase (Sigma-Aldrich, St. Louis, MO)]. YAN was measured using the assay described by Dukes and Butzke (1998). The malolactic fermentation was tracked using an enzyme assay (L-Malic Acid UniFLEX Reagent, UNitech Scientific, Hawaiian Gardens, CA).

\section{Wine sensory evaluation}

Starting in late February or early March of 2007, 2008 and 2009 , the wines from 2006, 2007 and 2008 respectively were evaluated by sensory descriptive analyses. Each year a newly trained descriptive analysis panel rated the perceived intensities of the sensory attributes of the wines (Lawless \& Heymann, 2010), using descriptors that discriminated among the samples. The 2006 wine panel (13 assessors) generated the seven aroma and six taste and mouthfeel attributes to be rated, and the reference standards, by consensus. The panel was trained over seven one-hour sessions. The wine panels for the 2007 and 2008 wines were trained to use the same attributes and reference standards using the ballot method (Lawless \& Heymann, 2010). Both the 2007 and the 2008 panels had 12 assessors and were trained over 16 one-hour sessions each year. See Table 3 for the descriptors and reference standards used for each vintage. Panel performance was evaluated using PanelCheck (www.panelcheck.com) and the data from a mock evaluation of a subset of the wines performed in triplicate. Once the panel performed to the expected standards (minimal wine-by-judge interactions, with reasonable discrimination and repeatability), the actual wine evaluation commenced.

The $30 \mathrm{ml}$ aliquots of the wines were served in three-digit coded clear ISO glasses. Six wines, individually randomised for each judge, were served in each session and the wines were randomised across sessions using a Williams-Latin square design. All wines were evaluated in triplicate and all the samples were expectorated. Evaluations were performed in individual sensory booths maintained at $20^{\circ} \mathrm{C}$, and data were entered using a $15 \mathrm{~cm}$ line scale, anchored by low and high intensity of the specified attribute, displayed on a computer (FIZZ, Couternon, France).

\section{Statistical data analysis}

The raw descriptive data for each of the three years were analysed individually by three-way analysis of variance (main effects wine, panellists and replications, and all twoway interactions). A significance level of alpha $<0.05$ was used in all cases. In cases where there were significant wine interactions, the pseudo mixed model was used to determine the effect on wine (Naes \& Langsrud, 1998). The 2006, 2007 and 2008 data were averaged across panellists and then standardised within each year and attribute. The datasets were combined and analysed by multivariate analysis of variance (MANOVA) and, if this was significant, canonical variate analysis (CVA) was performed. The $95 \%$ confidence intervals for each sample on the CVA were calculated using the Chatfield and Collins (1980) method. In all cases an alpha level of $5 \%$ was used.

The chemical data were analysed by one-way analysis of variance. All data analyses were performed using SAS version 9.2 (SI, Cary North Carolina) and data were plotted using XLSTAT (Addinsoft, New York, USA). 


\section{RESULTS AND DISCUSSION}

\section{Sensory and chemical effects on wines made from grapes} harvested over a wide range of ${ }^{\circ} \mathrm{Brix}$ levels

The intent had been to harvest six times each season at intervals of approximately $2^{\circ}$ Brix. Table 1 shows the actual harvest dates and the days post-véraison for each harvest. In 2007, harvests 4 and 5 were picked 22 days apart, but had identical sugar contents $\left(26.2^{\circ} \mathrm{Brix}\right)$. As can be seen in Tables $4 \mathrm{a}$ through $4 \mathrm{c}$, in each of the three vintages the wines made from grapes as harvested differed significantly in red fruit and cooked vegetative (cooked veg) aromas, sweet and bitter tastes and the mouthfeel attributes of hotness and astringency. In addition, the 2006 wines also differed significantly in dark fruit and fresh vegetative (fresh veg) aromas, sour taste and viscosity (Table 4a). The 2007 wines differed significantly in spicy aroma, sour taste and viscosity (Table 4b), and the 2008 wines differed significantly in fresh vegetative (fresh veg) and spicy aromas (Table 4c).

In the 2006 wines (Table 4a), the perceived red fruit and fresh vegetative aromas decreased when the wines were made from riper grapes. At the same time, the perceived dark fruit and dry fruit aromas increased. The cooked vegetative aroma decreased slightly for wines made from grapes harvested at about 26 and $27^{\circ}$ Brix, and then increased quite dramatically for wines made from grapes harvested at about $30{ }^{\circ}$ Brix. These increases could have been the result of increases in sulphur-containing compounds. Preston et al. (2008) have shown that green flavours in wine are more complex than just the concentration of isobutyl methoxy pyrazine, which one would expect to be very low in grapes picked at a high sugar content.

TABLE 4a

Significant sensory attributes for 2006 wines made from grapes harvested at different levels of ${ }^{\circ}$ Brix. The values are the actual unstandardised means.

\begin{tabular}{|c|c|c|c|c|c|c|}
\hline & $\begin{array}{l}\text { Red } \\
\text { fruit }^{1}\end{array}$ & $\begin{array}{l}\text { Dark } \\
\text { fruit }\end{array}$ & $\begin{array}{l}\text { Dry } \\
\text { fruit }\end{array}$ & $\begin{array}{c}\text { Fresh } \\
\text { veg }\end{array}$ & \multicolumn{2}{|c|}{$\begin{array}{l}\text { Cooked } \\
\text { veg }\end{array}$} \\
\hline $\mathrm{H} 1(22.4 \mathrm{~B})$ & $3.3 \mathrm{e}$ & $3.1 \mathrm{a}$ & $1.1 \mathrm{a}$ & $3.8 \mathrm{f}$ & \multicolumn{2}{|l|}{$2.0 \mathrm{c}$} \\
\hline $\mathrm{H} 2(23.1 \mathrm{~B})$ & $2.7 \mathrm{~b}$ & $3.7 \mathrm{~b}$ & $1.4 \mathrm{~b}$ & $2.9 \mathrm{~d}$ & \multicolumn{2}{|l|}{$2.1 \mathrm{~d}$} \\
\hline H3(24.7B) & $2.9 \mathrm{~d}$ & $4.1 \mathrm{~d}$ & $1.8 \mathrm{c}$ & $3.4 \mathrm{e}$ & \multicolumn{2}{|l|}{$2.1 \mathrm{~d}$} \\
\hline $\mathrm{H} 4(26.0 \mathrm{~B})$ & $2.8 \mathrm{c}$ & $4.4 \mathrm{e}$ & $1.8 \mathrm{c}$ & $2.8 \mathrm{c}$ & \multicolumn{2}{|l|}{$1.7 \mathrm{a}$} \\
\hline $\mathrm{H} 5(27.8 \mathrm{~B})$ & $2.9 \mathrm{~d}$ & $4.4 \mathrm{e}$ & $2.5 \mathrm{~d}$ & $2 \mathrm{~b}$ & \multicolumn{2}{|l|}{$1.8 \mathrm{~b}$} \\
\hline H6(30.7B) & $2.0 \mathrm{a}$ & $4 \mathrm{c}$ & $3.1 \mathrm{e}$ & $1.9 \mathrm{a}$ & \multicolumn{2}{|l|}{$3.1 \mathrm{e}$} \\
\hline $1 s d^{2}$ & 0.04 & 0.04 & 0.04 & 0.04 & \multicolumn{2}{|l|}{0.04} \\
\hline & Sweet & Sour & Bitter & Astringent & Hot & Viscous \\
\hline $\mathrm{H} 1(22.4 \mathrm{~B})$ & $1.1 \mathrm{a}$ & $4.0 \mathrm{e}$ & $3.1 \mathrm{~b}$ & $3.5 \mathrm{~b}$ & $2.8 \mathrm{a}$ & $1.6 \mathrm{a}$ \\
\hline $\mathrm{H} 2(23.1 \mathrm{~B})$ & $1.4 \mathrm{~b}$ & $3.0 \mathrm{~d}$ & $3.3 \mathrm{c}$ & $3.4 \mathrm{a}$ & $3.4 \mathrm{~b}$ & $2.2 \mathrm{~b}$ \\
\hline H3(24.7B) & $2.1 \mathrm{c}$ & $3.0 \mathrm{~d}$ & $3.6 \mathrm{~d}$ & $3.6 \mathrm{c}$ & $3.8 \mathrm{c}$ & $2.6 \mathrm{c}$ \\
\hline $\mathrm{H} 4(26.0 \mathrm{~B})$ & $3.6 \mathrm{~d}$ & $2.4 \mathrm{c}$ & $3.2 \mathrm{~b}$ & $4.0 \mathrm{~d}$ & $4.4 \mathrm{~d}$ & $3.3 \mathrm{~d}$ \\
\hline H5(27.8B) & $5 \mathrm{e}$ & $1.8 \mathrm{~b}$ & $2.9 \mathrm{a}$ & $3.5 \mathrm{~b}$ & $4.4 \mathrm{~d}$ & $4.2 \mathrm{e}$ \\
\hline H6(30.7B) & $6.5 \mathrm{f}$ & $1.3 \mathrm{a}$ & $2.9 \mathrm{a}$ & $3.5 \mathrm{~b}$ & $4.8 \mathrm{e}$ & $5.1 \mathrm{f}$ \\
\hline $1 s d^{2}$ & 0.03 & 0.03 & 0.04 & 0.04 & 0.03 & 0.03 \\
\hline
\end{tabular}

${ }^{1}$ Means followed by the same letter in the same column are not significantly different at $\mathrm{p}<0.05$.

${ }^{2}$ Fisher's protected least significant difference.
The trends were less clear in 2007 (Table 4b). The red fruit aromas peaked with wines made from grapes at about 25 ${ }^{\circ}$ Brix, while the cooked vegetative aromas peaked for wines made from grapes at about $22{ }^{\circ}$ Brix. Spicy aromas peaked for wines made from grapes at $30.8^{\circ}$ Brix. In 2007 , the fresh vegetative attribute did not differ significantly across wines made from grapes harvested at different levels of ripeness.

In 2008 (Table 4c), unlike in 2006, the perceived red fruit and spicy aromas increased in the wines from grapes harvested later, while the cooked vegetative aromas decreased. In 2008, unlike in 2007, the cooked vegetative aroma increased in the wines harvested later.

In all years the perceived sweetness increased in wines made from grapes harvested at higher ${ }^{\circ}$ Brix levels. This would be expected for the 2006 wines given the RS values, since the $2006 \mathrm{H} 6 \mathrm{NN}$ wines had become 'stuck' and had a very high (2.48\%; Table 5a) RS value, while the $2007 \mathrm{H} 6 \mathrm{NN}$ wines had an RS of $0.47 \%$ (slightly below what is considered to be the detection threshold) and the $2008 \mathrm{H} 5 \mathrm{NN}$ wines had a very low RS value of $0.03 \%$ (Tables $5 \mathrm{a}$ and $5 \mathrm{~b}$ ). The increased perception of sweetness therefore could be a halo effect, possibly due to the decreased perceived sourness and/ or the increased perceived viscosity or hotness of the wines. However, it is also possible that the ethanol itself contributed to this perceived sweetness. In a study by Scinska and coworkers (2000), approximately one-third of the population tested rated a $10 \% \mathrm{v} / \mathrm{v}$ ethanol solution as sweet. Using mice it has been shown that ethanol elicits both bitter and sweet tastes, with the sweet component dependent on the sweet taste receptor T1R3 (Murovets et al., 2009; Brasser et al., 2010).

TABLE $4 b$

Significant sensory attributes for 2007 wines made from grapes harvested at different levels of ${ }^{\circ}$ Brix. The values are the actual unstandardised means.

\begin{tabular}{|c|c|c|c|c|c|}
\hline & $\begin{array}{l}\text { Red } \\
\text { fruit }^{1}\end{array}$ & $\begin{array}{c}\text { Cooked } \\
\text { veg }\end{array}$ & Spicy & & \\
\hline H1(21.0B) & $2.2 \mathrm{c}$ & $1.5 \mathrm{c}$ & $1.8 \mathrm{~b}$ & & \\
\hline $\mathrm{H} 2(22.1 \mathrm{~B})$ & $2.0 \mathrm{a}$ & $1.8 \mathrm{~d}$ & $1.7 \mathrm{a}$ & & \\
\hline H3(24.6B) & $2.5 \mathrm{e}$ & $1.5 \mathrm{c}$ & $1.7 \mathrm{a}$ & & \\
\hline $\mathrm{H} 4(26.2 \mathrm{~B})$ & $2.2 \mathrm{c}$ & $1.3 \mathrm{a}$ & $1.8 \mathrm{~b}$ & & \\
\hline $\mathrm{H} 5(26.2 \mathrm{~B})$ & $2.4 \mathrm{~d}$ & $1.4 \mathrm{~b}$ & $1.7 \mathrm{a}$ & & \\
\hline $\mathrm{H} 6(30.8 \mathrm{~B})$ & $2.1 \mathrm{~b}$ & $1.5 \mathrm{c}$ & $2.4 \mathrm{c}$ & & \\
\hline \multirow[t]{2}{*}{$1 s d^{2}$} & 0.04 & 0.03 & 0.03 & & \\
\hline & Sweet & Sour & Bitter & Hot & Viscous \\
\hline H1(21.0B) & $1.3 \mathrm{a}$ & $5.1 \mathrm{e}$ & $2.4 \mathrm{a}$ & $2.3 \mathrm{a}$ & $2.5 \mathrm{a}$ \\
\hline $\mathrm{H} 2(22.1 \mathrm{~B})$ & $1.8 \mathrm{~b}$ & $4 \mathrm{~d}$ & $2.6 \mathrm{~b}$ & $2.7 \mathrm{~b}$ & $3.1 \mathrm{~b}$ \\
\hline H3(24.6B) & $2.2 \mathrm{c}$ & $3.6 \mathrm{c}$ & $2.7 \mathrm{c}$ & $2.9 \mathrm{c}$ & $3.1 \mathrm{~b}$ \\
\hline $\mathrm{H} 4(26.2 \mathrm{~B})$ & $2.6 \mathrm{~d}$ & $3.2 \mathrm{~b}$ & $3.0 \mathrm{~d}$ & $3.3 \mathrm{~d}$ & $3.3 \mathrm{c}$ \\
\hline $\mathrm{H} 5(26.2 \mathrm{~B})$ & $2.2 \mathrm{c}$ & $3.6 \mathrm{c}$ & $3.1 \mathrm{e}$ & $3.4 \mathrm{e}$ & $3.3 \mathrm{c}$ \\
\hline H6(30.8B) & $4.8 \mathrm{e}$ & $3.0 \mathrm{a}$ & $3.0 \mathrm{~d}$ & $4.2 \mathrm{f}$ & $4.2 \mathrm{~d}$ \\
\hline $1 s d^{2}$ & 0.03 & 0.04 & 0.04 & 0.03 & 0.03 \\
\hline
\end{tabular}

${ }^{1}$ Means followed by the same letter in the same column are not significantly different at $\mathrm{p}<0.05$.

${ }^{2}$ Fisher's protected least significant difference. 
TABLE 4c

Significant sensory attributes for 2008 wines made from grapes harvested at different levels of ${ }^{\circ}$ Brix. The values are the actual unstandardised means.

\begin{tabular}{lcccl}
\hline & Red fruit $^{1}$ & $\begin{array}{c}\text { Cooked } \\
\text { veg }\end{array}$ & Spicy & \\
\cline { 2 - 5 } H2(22.6B) & $2.4 \mathrm{~b}$ & $4.2 \mathrm{a}$ & $1.2 \mathrm{~b}$ & \\
$\mathrm{H} 3(23.2 \mathrm{~B})$ & $3.2 \mathrm{ab}$ & $2.5 \mathrm{~b}$ & $1.3 \mathrm{~b}$ & \\
$\mathrm{H} 4(25.0 \mathrm{~B})$ & $3.3 \mathrm{a}$ & $1.9 \mathrm{c}$ & $1.6 \mathrm{~b}$ & \\
$\mathrm{H} 5(36.6 \mathrm{~B})$ & $3.4 \mathrm{a}$ & $1.6 \mathrm{c}$ & $2.2 \mathrm{a}$ & \\
lsd $^{2}$ & 0.60 & 0.59 & 0.43 & \\
& & & & \\
$\mathrm{H} 2(22.6 \mathrm{~B})$ & $1.0 \mathrm{c}$ & $3.1 \mathrm{~b}$ & $2.9 \mathrm{~b}$ & $2.1 \mathrm{c}$ \\
$\mathrm{H} 3(23.2 \mathrm{~B})$ & $1.3 \mathrm{bc}$ & $3.5 \mathrm{~b}$ & $3.3 \mathrm{~b}$ & $2.5 \mathrm{c}$ \\
$\mathrm{H} 4(25.0 \mathrm{~B})$ & $1.5 \mathrm{~b}$ & $3.2 \mathrm{~b}$ & $3.7 \mathrm{a}$ & $3.4 \mathrm{~b}$ \\
$\mathrm{H} 5(36.6 \mathrm{~B})$ & $2.2 \mathrm{a}$ & $4.7 \mathrm{a}$ & $3.8 \mathrm{a}$ & $5.4 \mathrm{a}$ \\
$1 \mathrm{sd}{ }^{2}$ & 0.38 & 0.44 & 0.49 & 0.49 \\
\hline
\end{tabular}

${ }^{1}$ Means followed by the same letter in the same column are not significantly different at $\mathrm{p}<0.05$.

${ }^{2}$ Fisher's protected least significant difference.
In all years, the perceived hotness of the wines made from grapes with a higher ${ }^{\circ}$ Brix level was much higher than in wines made from grapes with a lower ${ }^{\circ}$ Brix level (Tables 5a and $5 \mathrm{~b}$ ). The trend for increased perceived hotness follows that of the actual alcohol concentrations of the wines. This was also shown for commercial US Cabernet Sauvignon by Hjelmeland and coworkers (2012), as well as King and coworkers (2013).

The perceived sourness of the wines made from riper grapes was significantly lower than the sourness perception of wines made with less ripe grapes in 2006 and 2007, but in 2008 these effects were not significant (Tables 4a to 4c). This does not agree with the TA values, where the later harvests had higher values than the earlier ones, but it does agree with the $\mathrm{pH}$ values (Tables 5a and $5 \mathrm{~b}$ ).

The MANOVA of the combined data was significant and all the attributes, except astringency and viscosity, were discriminated among the wines. The CVA combining the 2006, 2007 and 2008 wines explained nearly $75 \%$ of the variance ratio in the first two dimensions. This analysis has 64 wine treatment-year combinations and ten attributes. To improve clarity, the plots were divided into four plots. In Fig. 1 the wines made from grapes as harvested are shown, and the loadings on this plot indicate that, in the horizontal dimension, as the grapes the ripened, the wines decreased in

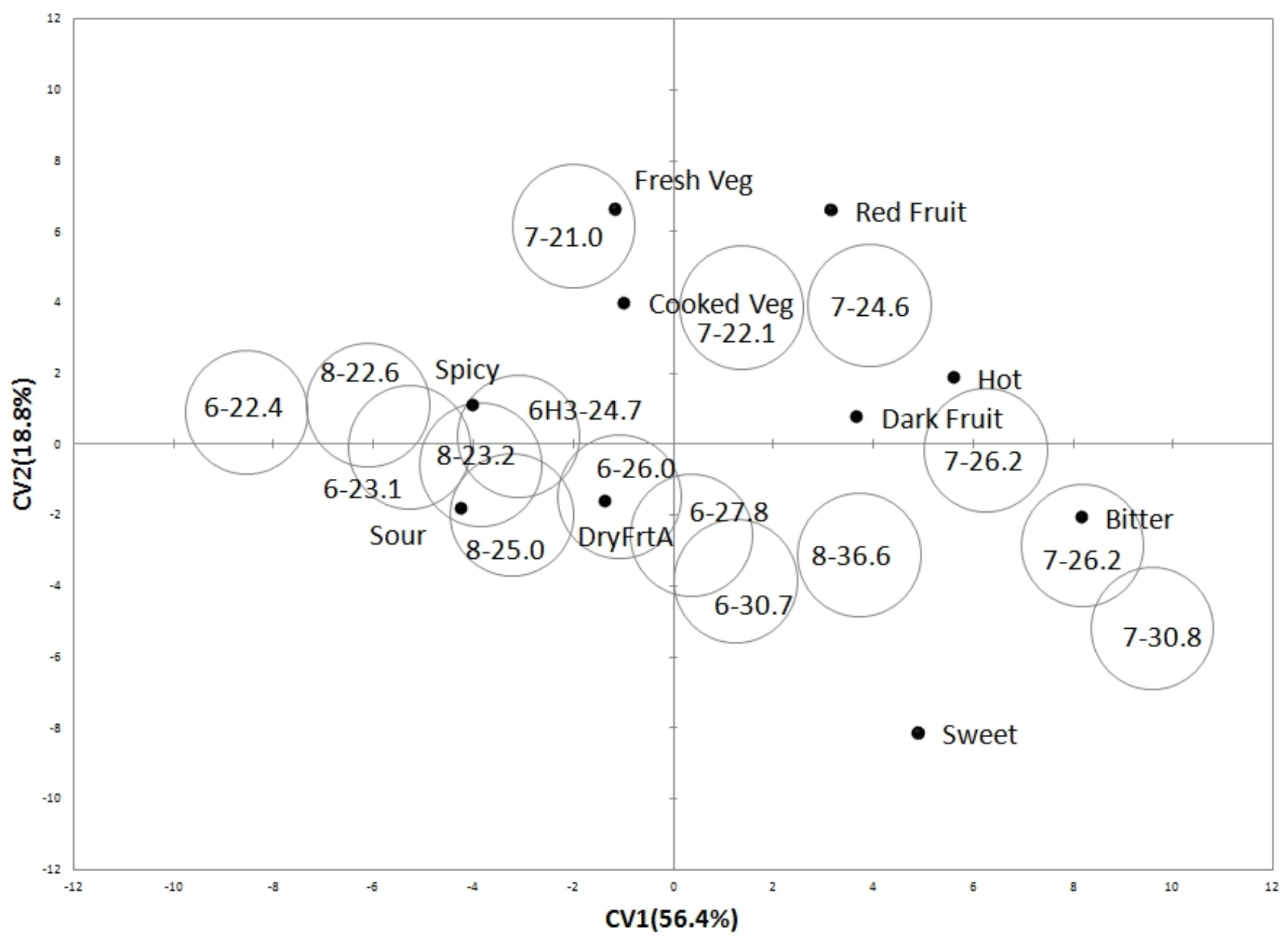

FIGURE 1

Canonical variate analysis (CVA) for the wines made without additions. The loadings indicate the significant sensory descriptors separating the 2006, 2007 and 2008 wines. The CV scores for each harvest's wines are enclosed by a 95\% confidence ellipse and the ${ }^{\circ}$ Brix level at each harvest is indicated. 
TABLE 5a

Titratable acidity (TA), pH, ethanol and residual sugar (RS) concentrations for the 2006 and 2007 wines.

\begin{tabular}{|c|c|c|c|c|c|c|c|c|}
\hline \multirow{2}{*}{ Wine } & \multicolumn{4}{|c|}{2006} & \multicolumn{4}{|c|}{2007} \\
\hline & $\mathrm{TA}^{1,2}$ & $\mathrm{pH}$ & Ethanol $^{1}$ & $\mathrm{RS}^{1}$ & $\mathrm{TA}^{1}$ & $\mathrm{pH}$ & Ethanol $^{1}$ & $\mathrm{RS}^{1}$ \\
\hline H1NN & $5.01 \mathrm{efgh}$ & $3.88 \mathrm{i}$ & 11.321 & $0.01 \mathrm{e}$ & $5.28 \mathrm{efg}$ & $3.75 \mathrm{mn}$ & $11.24 \mathrm{i}$ & $0.02 \mathrm{de}$ \\
\hline H1NA & 4.62hij & $3.92 \mathrm{hi}$ & $13.86 \mathrm{ef}$ & $0.05 \mathrm{e}$ & $5.09 \mathrm{fg}$ & $3.79 \mathrm{~m}$ & $12.00 \mathrm{fg}$ & $0.02 \mathrm{de}$ \\
\hline $\mathrm{H} 1 \mathrm{BN}$ & 4.79ghi & 3.93hi & $12.26 \mathrm{k}$ & $0.04 \mathrm{e}$ & $5.29 \mathrm{efg}$ & $3.71 \mathrm{n}$ & $11.61 \mathrm{~h}$ & $0.04 \mathrm{cde}$ \\
\hline H1BA & $4.53 \mathrm{ij}$ & $3.95 \mathrm{gh}$ & $15.15 \mathrm{cde}$ & $0.04 \mathrm{e}$ & 5.31efg & $3.78 \mathrm{~m}$ & $11.88 \mathrm{fgh}$ & $0.03 \mathrm{de}$ \\
\hline $\mathrm{H} 2 \mathrm{NN}$ & 4.54ij & $4.05 \mathrm{ef}$ & $12.60 \mathrm{j}$ & $0.05 \mathrm{e}$ & $5.05 \mathrm{fg}$ & $4.04 \mathrm{cde}$ & $12.11 \mathrm{fg}$ & $0.06 \mathrm{cde}$ \\
\hline $\mathrm{H} 2 \mathrm{NA}$ & $4.28 \mathrm{j}$ & $4.07 \mathrm{cdef}$ & $14.18 \mathrm{cde}$ & $0.04 \mathrm{e}$ & $5.00 \mathrm{fg}$ & $4.04 \mathrm{cde}$ & $12.10 \mathrm{fg}$ & $0.07 \mathrm{cde}$ \\
\hline $\mathrm{H} 2 \mathrm{BN}$ & 4.66hij & $4.01 \mathrm{fg}$ & $12.75 \mathrm{ij}$ & $0.09 \mathrm{e}$ & $5.81 \mathrm{bcd}$ & $3.89 \mathrm{jkl}$ & $12.04 \mathrm{fg}$ & $0.03 \mathrm{cde}$ \\
\hline $\mathrm{H} 2 \mathrm{BA}$ & 4.44ij & $4.02 \mathrm{efg}$ & $13.68 \mathrm{fgh}$ & $0.08 \mathrm{e}$ & 5.38def & 3.92ijk & $11.79 \mathrm{gh}$ & $0.05 \mathrm{cde}$ \\
\hline $\mathrm{H} 3 \mathrm{NN}$ & 4.94fghi & $4.09 \mathrm{cde}$ & $13.46 \mathrm{~h}$ & $0.33 \mathrm{cde}$ & $5.99 \mathrm{bc}$ & $3.88 \mathrm{kl}$ & $12.7 \mathrm{e}$ & $0.01 \mathrm{e}$ \\
\hline H3NA & 4.97efgh & $4.11 \mathrm{bcde}$ & 14.12cdef & $0.36 \mathrm{cde}$ & $5.83 \mathrm{bcd}$ & 3.871 & $12.19 \mathrm{f}$ & $0.00 \mathrm{e}$ \\
\hline $\mathrm{H} 3 \mathrm{BN}$ & 5.11defg & $4.06 \mathrm{ef}$ & $13.04 \mathrm{i}$ & $0.11 \mathrm{de}$ & $5.89 \mathrm{bc}$ & $3.91 \mathrm{jk}$ & $12.30 \mathrm{f}$ & $0.00 \mathrm{e}$ \\
\hline H3BA & $4.58 \mathrm{ij}$ & $4.13 b c$ & $13.81 \mathrm{fg}$ & $0.14 \mathrm{cde}$ & $5.91 b c$ & $3.95 \mathrm{ijk}$ & $12.30 \mathrm{f}$ & $0.00 \mathrm{e}$ \\
\hline H4NN & $5.71 \mathrm{~b}$ & $4.07 \mathrm{cdef}$ & $14.47 \mathrm{c}$ & $0.46 b c$ & $5.94 b c$ & 3.96ghi & $13.42 \mathrm{c}$ & $0.02 \mathrm{de}$ \\
\hline H4NA & $5.39 \mathrm{bcde}$ & $4.12 \mathrm{bcd}$ & $14.99 \mathrm{~b}$ & $0.41 \mathrm{~cd}$ & $5.26 \mathrm{efg}$ & 3.94hij & $11.95 \mathrm{fg}$ & $0.00 \mathrm{e}$ \\
\hline H4BN & $5.49 \mathrm{bcd}$ & $4.08 \mathrm{cde}$ & $13.52 \mathrm{gh}$ & $0.12 \mathrm{de}$ & $5.65 \mathrm{cde}$ & 3.94hij & $12.69 \mathrm{e}$ & $0.01 \mathrm{e}$ \\
\hline H4BA & $5.27 \mathrm{cdef}$ & $4.10 \mathrm{cde}$ & $14.44 \mathrm{c}$ & $0.12 \mathrm{de}$ & $5.57 \mathrm{cde}$ & $3.90 \mathrm{jkl}$ & $12.07 \mathrm{fg}$ & $0.01 \mathrm{e}$ \\
\hline $\mathrm{H} 5 \mathrm{NN}$ & $6.18 \mathrm{a}$ & $4.05 \mathrm{ef}$ & $14.91 \mathrm{~b}$ & $0.78 b$ & $5.32 \mathrm{~g}$ & $4.05 \mathrm{~cd}$ & $13.74 \mathrm{c}$ & $0.10 \mathrm{~cd}$ \\
\hline H5NA & $5.28 \mathrm{cdef}$ & $4.18 b$ & $14.87 \mathrm{~b}$ & $0.77 b$ & $4.92 \mathrm{efg}$ & 4.00defg & $12.20 \mathrm{f}$ & $0.08 \mathrm{cde}$ \\
\hline H5BN & $5.39 \mathrm{bcde}$ & $4.06 \mathrm{def}$ & $13.96 \mathrm{def}$ & $0.11 \mathrm{de}$ & $5.64 \mathrm{cde}$ & $4.01 \mathrm{def}$ & $13.08 \mathrm{~d}$ & $0.08 \mathrm{cde}$ \\
\hline H5BA & $5.24 \mathrm{cdef}$ & $4.12 \mathrm{bcd}$ & $14.48 \mathrm{c}$ & $0.11 \mathrm{de}$ & 5.39def & $3.97 \mathrm{fgh}$ & $12.13 \mathrm{f}$ & $0.06 \mathrm{cde}$ \\
\hline H6NN & $5.43 \mathrm{bcde}$ & $4.34 \mathrm{a}$ & $15.91 \mathrm{a}$ & $2.48 \mathrm{a}$ & $6.18 \mathrm{a}$ & $4.38 \mathrm{a}$ & $16.69 \mathrm{a}$ & $0.47 \mathrm{a}$ \\
\hline H6NA & $5.58 \mathrm{bc}$ & $4.29 a$ & $15.74 \mathrm{a}$ & $2.34 \mathrm{a}$ & $6.63 a$ & $3.99 \mathrm{efg}$ & $11.99 \mathrm{fg}$ & $0.12 \mathrm{c}$ \\
\hline H6BN & $5.77 \mathrm{ab}$ & $4.09 \mathrm{cde}$ & $14.18 \mathrm{cde}$ & $0.07 \mathrm{e}$ & $5.57 \mathrm{cde}$ & $4.14 b$ & $15.14 \mathrm{~b}$ & $0.26 \mathrm{~b}$ \\
\hline H6BA & $6.20 \mathrm{a}$ & $4.04 \mathrm{ef}$ & $14.28 \mathrm{~cd}$ & $0.06 \mathrm{e}$ & $5.04 \mathrm{fg}$ & $4.08 \mathrm{bc}$ & $12.32 \mathrm{ef}$ & $0.01 \mathrm{de}$ \\
\hline $1 \mathrm{sd}^{3}$ & 0.41 & 0.06 & 0.32 & 0.32 & 0.46 & 0.50 & 0.32 & 0.08 \\
\hline
\end{tabular}

${ }^{1} \mathrm{TA}$ in $\mathrm{g} / \mathrm{L}$; Ethanol in $\% \mathrm{v} / \mathrm{v}$; RS in $\%$.

${ }^{2}$ Means followed by the same letter in the same column are not significantly different at $\mathrm{p}<0.05$.

${ }^{3}$ Fisher's protected least significant difference.

perceived sourness, spiciness, fresh and cooked vegetative aromas and increased in dark fruit aromas, hotness, bitterness and sweetness. The vertical dimension separated the 2007 vintage from the other two, as this vintage was higher in fresh vegetative and red fruit aromas than the 2006 and 2008 vintages. The proximity of bitter and sweet on the plot was a little disconcerting, since usually these two attributes would be negatively correlated. However, the sensory values for these attributes (Table 4c) show that the wines made from the last harvest in 2008, picked at 36.6 and watered back to 30 , were perceived to be much more bitter than any of the wines made in 2006 and 2007 (Tables 4a and 4b). The 2007 wines were intermediate between the 2006 and 2008 wines on this plot. For all the vintages, wines made from the earlier harvests were more sour, despite the TA of all the musts being adjusted to $7 \mathrm{~g} / \mathrm{L}$ prior to fermentation. This could be due to a masking effect, as the wines from grapes harvested later were progressively more sweet and hot, which would mask the sourness of these wines. These effects have been studied by Zamora et al. (2006) and Scinska et al. (2000). This research showed that, during grape maturation from about 20 to $30^{\circ} \mathrm{Brix}$, the sensory attributes of wines made from these grapes vary in a systematic fashion. Specifically, the wines made from the lower ${ }^{\circ}$ Brix grapes are sourer and have more fresh vegetative flavours, while the wines made from the high ${ }^{\circ}$ Brix fruit are hotter, more bitter and, in some cases, have more dark fruit flavours and sweetness.

Sensory and chemical effects on wines made by manipulating their alcohol content by chaptalisation and/or fortification or watering back

The expectation was that manipulating the initial sugar content prior to fermentation and/or the final alcohol content after fermentation would have a number of consequences. These were (a) a change in the final alcohol content of the wines, (b) less likelihood of stuck fermentations by the 
TABLE $5 b$

Titratable acidity (TA), $\mathrm{pH}$, ethanol and residual sugar (RS) concentrations for the 2008 wines.

\begin{tabular}{lllll}
\hline Wine & TA $^{1,2}$ & \multicolumn{1}{c}{$\mathrm{pH}$} & Ethanol $^{1}$ & \multicolumn{1}{c}{ RS $^{1}$} \\
\hline H2NN & $5.64 \mathrm{~cd}$ & $4.14 \mathrm{ab}$ & $10.00 \mathrm{gh}$ & $0.02 \mathrm{abcd}$ \\
H2NA & $5.69 \mathrm{~cd}$ & $4.14 \mathrm{ab}$ & $11.41 \mathrm{e}$ & $0.00 \mathrm{~d}$ \\
H2BN & $6.08 \mathrm{bc}$ & $3.96 \mathrm{def}$ & $10.16 \mathrm{~g}$ & $0.01 \mathrm{~cd}$ \\
H2BA & $5.68 \mathrm{bc}$ & $3.99 \mathrm{cde}$ & $11.33 \mathrm{e}$ & $0.00 \mathrm{~d}$ \\
& & & & \\
H3NN & $6.06 \mathrm{bc}$ & $3.97 \mathrm{def}$ & $10.88 \mathrm{f}$ & $0.00 \mathrm{~d}$ \\
H3NA & $5.87 \mathrm{bc}$ & $3.98 \mathrm{cdef}$ & $11.42 \mathrm{e}$ & $0.00 \mathrm{~d}$ \\
H3BN & $6.02 \mathrm{bc}$ & $3.99 \mathrm{cde}$ & $11.37 \mathrm{e}$ & $0.00 \mathrm{~d}$ \\
H3BA & $5.93 \mathrm{bc}$ & $3.99 \mathrm{cde}$ & $11.50 \mathrm{e}$ & $0.00 \mathrm{~d}$ \\
H4NN & $5.87 \mathrm{bc}$ & $4.08 \mathrm{abc}$ & $12.57 \mathrm{c}$ & $0.02 \mathrm{abc}$ \\
H4NA & $5.52 \mathrm{~cd}$ & $4.05 \mathrm{bcd}$ & $11.54 \mathrm{e}$ & $0.01 \mathrm{bcd}$ \\
H4BN & $5.96 \mathrm{bc}$ & $4.04 \mathrm{bcd}$ & $11.99 \mathrm{~d}$ & $0.02 \mathrm{abcd}$ \\
H4BA & $5.81 \mathrm{bc}$ & $4.03 \mathrm{~cd}$ & $11.57 \mathrm{e}$ & $0.02 \mathrm{abcd}$ \\
H5NN & $6.10 \mathrm{bc}$ & $4.18 \mathrm{a}$ & $16.13 \mathrm{a}$ & $0.03 \mathrm{ab}$ \\
H5NA & $5.16 \mathrm{~d}$ & $3.88 \mathrm{f}$ & $9.77 \mathrm{~h}$ & $0.03 \mathrm{ab}$ \\
H5BN & $6.74 \mathrm{a}$ & $3.99 \mathrm{cde}$ & $13.46 \mathrm{~b}$ & $0.03 \mathrm{ab}$ \\
H5BA & $6.32 \mathrm{ab}$ & $3.92 \mathrm{ef}$ & $11.31 \mathrm{e}$ & $0.03 \mathrm{a}$ \\
$1 \mathrm{sd}{ }^{3}$ & 0.16 & 0.10 & 0.06 & 0.01 \\
\hline
\end{tabular}

${ }^{1} \mathrm{TA}$ in $\mathrm{g} / \mathrm{l}$; Ethanol in $\% \mathrm{v} / \mathrm{v}$; RS in $\%$.

${ }^{2}$ Means followed by the same letter in the same column are not significantly different at $\mathrm{p}<0.05$.

${ }^{3}$ Fisher's protected least significant difference.

wines made from grapes harvested at high sugar contents, and (c) probably not much change in $\mathrm{pH}$ beyond that of the added water.

\section{Chemical effects of manipulating must and/or wine}

The following sections refer to Tables 5a and 5b. In 2006 and 2007, the H1BN wines had an increased alcohol concentration over the H1NN wines, but for H2BN the alcohol content of the chaptalised wines did not differ from that of the unchaptalised wines in all three years, probably due to the small amount of sugar needed to change the ${ }^{\circ}$ Brix value to 24. The alcohol concentrations of the 2006 and 2007 $\mathrm{H} 3 \mathrm{BN}$ wines were actually significantly lower than their NN counterparts, despite the addition of a small amount of sugar to the $\mathrm{BN}$ wines prior to fermentation.

In this study we attempted to manipulate the wines' alcohol content by either chaptalising or watering before fermentation, or by fortifying or watering after fermentation, or both (Table 2). We were not extremely successful, as wines fortified after fermentation usually were higher in alcohol than their NN counterparts, whereas wines that were chaptalised before fermentation and then fortified after fortification tended to be very high in alcohol content, for example 2006 H1BA. In all years, the BN wines that had water added before fermentation were significantly lower in final wine alcohol concentration than their respective NN wines. Wines that had water added only after fermentation tended to have a lower final alcohol content than their NN counterparts, although an exception was the 2006 H4NA wine, which was higher in alcohol than its NN counterpart.

The $\mathrm{pH}$ values of the manipulated wines were quite similar within a harvest and year, with the largest variability being a $\mathrm{pH}$ value of about 0.1 . Similarly, the TA values in the finished wines varied less the 0.12 within a harvest and year. In 2006 the wines that did not have water added prior to fermentation became 'stuck', and their RS values were above $2.3 \%$. The 2007 and 2008 wines made from the last harvest fermented dry, despite the high must sugar concentration of about $30{ }^{\circ}$ Brix.

\section{Sensory effects associated with manipulating must and/or wines \\ Harvest 1}

In 2006, chaptalising before fermentation did not affect the perception of sweetness for wines made from Harvest 1 grapes, but fortification with alcohol after fermentation did significantly increase the perception of sweetness, bitterness, astringency, hotness and viscosity (Table 6a). Fortification significantly decreased the perception of sourness. These results are in agreement with the increases in alcohol content of the fortified and chaptalised wines (Table 5a). For the 2007 wines the effect of chaptalisation and/or fortification on sweetness, hotness and viscosity was significant, but there were only small increases. The combination of chaptalisation and fortification decreased perceived sourness slightly, while chaptalisation alone increased perceived sourness slightly. Fortification only slightly decreased perceived bitterness, but chaptalisation alone or with fortification increased perceived bitterness (Table 6b).

The effects of the treatments (chaptalisation and/or fortification) were not as significant on the aroma attributes. The major effect in 2006 was the decrease in fresh vegetative aroma with chaptalisation and/or fortification (Table 6a). For the 2007 wines there essentially were no differences in the perceived aromas due to treatments (Table $6 \mathrm{~b}$ ).

\section{Harvest 2}

In 2006 there were a few notable differences in the wines according to treatment, with increased bitterness, astringency and hotness due to fortification being the most noteworthy. The red fruit aroma of the untreated wine was less than this aroma for wines that had been chaptalised and/or fortified, while the effect on the cooked vegetative aroma was the opposite (Table 6a). For the 2007 wines, the effects were less clear for taste and aroma attributes (Table 6b). For the 2008 wines the cooked vegetative aromas of the untreated wines were perceptibly higher than these aromas in chaptalised and/or fortified wines (Table 6c). Fortification both before and after fermentation increased perceived bitterness, but chaptalisation alone decreased the perception of this attribute. The perception of astringency increased with all treatments, as did the perception of hotness in the mouth.

\section{Harvest 3}

The sensory effects of adding water to the must and/or the wine prior to bottling were statistically significant, but very small in 2006 and 2007 (Tables 6a and 6b). One of the two exceptions was addition of water prior to bottling 
TABLE 6a

Significant sensory aroma attributes for 2006 wines made from grapes harvested at different levels of ${ }^{\circ}$ Brix and chaptalised and/or fortified or watered back. The values are the actual unstandardised means.

\begin{tabular}{|c|c|c|c|c|c|}
\hline & $\begin{array}{l}\text { Red } \\
\text { fruit }\end{array}$ & $\begin{array}{l}\text { Dark } \\
\text { fruit }\end{array}$ & $\begin{array}{l}\text { Dry } \\
\text { fruit }\end{array}$ & $\begin{array}{c}\text { Fresh } \\
\text { veg }\end{array}$ & $\begin{array}{c}\text { Cooked } \\
\text { veg }\end{array}$ \\
\hline H1NN & 3.3 & 3.1 & 1.1 & 3.8 & 2.0 \\
\hline H1NA & 3.4 & 3.3 & 1.2 & 3.3 & 1.8 \\
\hline $\mathrm{H} 1 \mathrm{BN}$ & 3.1 & 3.3 & 1.3 & 3.5 & 1.9 \\
\hline H1BA & 3.3 & 3.5 & 1.2 & 3.1 & 1.9 \\
\hline $\mathrm{H} 2 \mathrm{NN}$ & 2.7 & 3.7 & 1.4 & 2.9 & 2.1 \\
\hline $\mathrm{H} 2 \mathrm{NA}$ & 3.0 & 3.7 & 1.5 & 2.9 & 1.7 \\
\hline $\mathrm{H} 2 \mathrm{BN}$ & 3.2 & 3.9 & 1.6 & 2.6 & 1.4 \\
\hline $\mathrm{H} 2 \mathrm{BA}$ & 3.2 & 3.7 & 1.4 & 2.8 & 1.7 \\
\hline $\mathrm{H} 3 \mathrm{NN}$ & 2.9 & 4.1 & 1.8 & 3.4 & 2.1 \\
\hline H3NA & 2.7 & 4.3 & 1.7 & 3.0 & 2.2 \\
\hline $\mathrm{H} 3 \mathrm{BN}$ & 3.2 & 3.6 & 1.4 & 3.2 & 2.2 \\
\hline H3BA & 3.1 & 3.9 & 1.5 & 3.1 & 2.1 \\
\hline $\mathrm{H} 4 \mathrm{NN}$ & 2.8 & 4.4 & 1.8 & 2.8 & 1.7 \\
\hline H4NA & 2.7 & 3.9 & 1.7 & 2.4 & 1.6 \\
\hline $\mathrm{H} 4 \mathrm{BN}$ & 2.9 & 4.3 & 1.9 & 2.4 & 1.6 \\
\hline H4BA & 2.7 & 4.3 & 2.1 & 2.2 & 1.5 \\
\hline H5NN & 2.9 & 4.4 & 2.5 & 2.0 & 1.8 \\
\hline H5NA & 2.6 & 4.4 & 2.4 & 2.3 & 1.6 \\
\hline $\mathrm{H} 5 \mathrm{BN}$ & 2.8 & 4.0 & 2.1 & 2.1 & 1.4 \\
\hline H5BA & 2.9 & 4.2 & 2.3 & 2.1 & 1.4 \\
\hline H6NN & 2.0 & 4.0 & 3.1 & 1.9 & 3.1 \\
\hline H6NA & 2.2 & 3.9 & 2.9 & 1.9 & 2.9 \\
\hline H6BN & 2.5 & 4.1 & 2.2 & 2.1 & 2.2 \\
\hline H6BA & 2.7 & 4.0 & 2.6 & 2.3 & 1.8 \\
\hline lsd & 0.04 & 0.04 & 0.04 & 0.04 & 0.04 \\
\hline
\end{tabular}

but not before fermentation, which increased the perceived sweetness of the 2006 wines. The other exception also occurred in 2006, where the addition of water prior to fermentation decreased the perceived dark fruit aroma, while the addition of water prior to bottling increased the perceived dark fruit aroma. In 2008 the Harvest 3 musts were chaptalised and/or fortified (Table 6c). The effects of these treatments were significant but minor, with the exception of red fruit and cooked vegetative aromas.

\section{Harvest 4}

In 2006 and 2007, adding water to the must (or wine) decreased the sweetness perception of the resulting wines when compared to the wine made with no water addition (Tables 6a and 6b). The opposite occurred when water was added to the must in 2008 (Table 6c). In 2006, the other taste
TABLE 6a (CONTINUED).

Significant sensory taste and mouthfeel attributes for 2006 wines made from grapes harvested at different levels of ${ }^{\circ}$ Brix and chaptalised and/or fortified or watered back. The values are the actual unstandardised means.

\begin{tabular}{|c|c|c|c|c|c|c|}
\hline & Sweet & Sour & Bitter & Astringent & Hot & Viscous \\
\hline H1NN & 1.1 & 4.0 & 3.1 & 3.5 & 2.8 & 1.6 \\
\hline H1NA & 1.3 & 3.5 & 4.1 & 3.9 & 3.7 & 2.2 \\
\hline H1BN & 1.1 & 3.8 & 3.5 & 3.5 & 3.2 & 1.8 \\
\hline H1BA & 1.5 & 3.4 & 4.2 & 3.9 & 3.9 & 2.2 \\
\hline $\mathrm{H} 2 \mathrm{NN}$ & 1.4 & 3.0 & 3.3 & 3.4 & 3.4 & 2.2 \\
\hline $\mathrm{H} 2 \mathrm{NA}$ & 1.6 & 3.0 & 4.0 & 4.0 & 4.0 & 2.4 \\
\hline $\mathrm{H} 2 \mathrm{BN}$ & 1.4 & 3.5 & 3.4 & 3.5 & 3.4 & 2.3 \\
\hline $\mathrm{H} 2 \mathrm{BA}$ & 1.4 & 3.0 & 3.9 & 4.0 & 3.7 & 2.4 \\
\hline $\mathrm{H} 3 \mathrm{NN}$ & 2.1 & 3.0 & 3.6 & 3.6 & 3.8 & 2.6 \\
\hline H3NA & 2.6 & 2.8 & 3.5 & 3.9 & 3.9 & 2.8 \\
\hline H3BN & 1.9 & 3.0 & 3.5 & 3.5 & 3.4 & 2.7 \\
\hline H3BA & 1.9 & 2.9 & 3.7 & 3.8 & 3.9 & 2.7 \\
\hline $\mathrm{H} 4 \mathrm{NN}$ & 3.6 & 2.4 & 3.2 & 4.0 & 4.4 & 3.3 \\
\hline H4NA & 3.3 & 2.4 & 3.3 & 4.0 & 4.5 & 3.3 \\
\hline $\mathrm{H} 4 \mathrm{BN}$ & 2.1 & 2.8 & 3.5 & 3.8 & 3.9 & 2.7 \\
\hline H4BA & 2.5 & 2.7 & 3.7 & 3.9 & 4.3 & 2.8 \\
\hline $\mathrm{H} 5 \mathrm{NN}$ & 5.0 & 1.8 & 2.9 & 3.5 & 4.4 & 4.2 \\
\hline H5NA & 5.1 & 1.8 & 3.0 & 3.7 & 4.4 & 4.1 \\
\hline $\mathrm{H} 5 \mathrm{BN}$ & 2.5 & 2.8 & 3.6 & 3.9 & 4.1 & 3.1 \\
\hline H5BA & 2.7 & 2.6 & 3.9 & 3.7 & 4.3 & 3.1 \\
\hline H6NN & 6.5 & 1.3 & 2.9 & 3.5 & 4.8 & 5.1 \\
\hline H6NA & 6.6 & 1.3 & 2.4 & 3.5 & 4.4 & 5.3 \\
\hline H6BN & 2.6 & 2.5 & 3.6 & 3.7 & 4.2 & 3.1 \\
\hline H6BA & 2.9 & 2.5 & 3.5 & 3.4 & 4.2 & 3.3 \\
\hline lsd & 0.03 & 0.03 & 0.04 & 0.04 & 0.03 & 0.03 \\
\hline
\end{tabular}

effects were not as large or clear. Water addition in 2007 also decreased perceived bitterness, astringency, hotness and viscosity. In 2008, water addition decreased perceived sourness, astringency and hotness. In the case of astringency and hotness these effects were most pronounced when water was added to the wines after fermentation. In 2006, watering must and/or wine led to perceived decreases in the intensity of fresh vegetative aroma and, in the case of dark fruit aroma, the decreased perception occurred in wines that had only been watered down after fermentation. For the 2007 wines the perception of red fruit aroma increased, especially for wines that had water added both before and after fermentation. The water addition to the 2008 wines after fermentation increased perceived fresh vegetative aromas. Water addition to wine also increased perceived red fruit aromas. 
TABLE $6 b$

Significant sensory aroma attributes for 2007 wines made from grapes harvested at different levels of ${ }^{\circ}$ Brix and chaptalised and/or fortified or watered back. The values are the actual unstandardised means.

\begin{tabular}{|c|c|c|c|}
\hline & Red fruit & Cooked veg & Spicy \\
\hline H1NN & 2.2 & 1.5 & 1.8 \\
\hline H1NA & 2.2 & 1.6 & 2.0 \\
\hline $\mathrm{H} 1 \mathrm{BN}$ & 2.4 & 1.5 & 1.9 \\
\hline H1BA & 2.0 & 1.5 & 1.8 \\
\hline $\mathrm{H} 2 \mathrm{NN}$ & 2.0 & 1.8 & 1.7 \\
\hline $\mathrm{H} 2 \mathrm{NA}$ & 2.1 & 1.6 & 1.7 \\
\hline $\mathrm{H} 2 \mathrm{BN}$ & 2.4 & 1.6 & 1.6 \\
\hline $\mathrm{H} 2 \mathrm{BA}$ & 2.4 & 1.8 & 1.7 \\
\hline $\mathrm{H} 3 \mathrm{NN}$ & 2.5 & 1.5 & 1.7 \\
\hline H3NA & 2.2 & 1.8 & 1.8 \\
\hline $\mathrm{H} 3 \mathrm{BN}$ & 2.3 & 1.5 & 1.6 \\
\hline H3BA & 2.3 & 1.2 & 1.6 \\
\hline $\mathrm{H} 4 \mathrm{NN}$ & 2.2 & 1.3 & 1.8 \\
\hline H4NA & 2.5 & 1.3 & 1.8 \\
\hline $\mathrm{H} 4 \mathrm{BN}$ & 2.4 & 1.2 & 1.7 \\
\hline H4BA & 2.8 & 1.1 & 1.8 \\
\hline $\mathrm{H} 5 \mathrm{NN}$ & 2.4 & 1.4 & 1.7 \\
\hline H5NA & 2.6 & 1.3 & 1.8 \\
\hline $\mathrm{H} 5 \mathrm{BN}$ & 2.3 & 1.5 & 2.0 \\
\hline H5BA & 2.8 & 1.4 & 1.8 \\
\hline H6NN & 2.1 & 1.5 & 2.4 \\
\hline H6NA & 2.1 & 1.4 & 2.4 \\
\hline H6BN & 2.6 & 1.1 & 2.5 \\
\hline H6BA & 1.6 & 1.0 & 1.8 \\
\hline 1sd & 0.04 & 0.03 & 0.03 \\
\hline
\end{tabular}

\section{Harvest 5}

In 2006, adding water to the must resulted in wines that were lower in perceived intensity of sweetness and viscosity and higher in perceived intensity of sourness and bitterness (Table 6a). The results for 2007 were similar to the 2007 Harvest 4 results in that water addition, either before and/ or after fermentation, decreased perceived bitterness (Table 6b). Water addition after fermentation decreased perceived hotness and, to a lesser extent, viscosity. In 2006 and 2007, adding water did not have a clear effect on the aroma attributes of the wines made from Harvest 5. The only exception occurred in 2007, when the addition of water both before and after fermentation increased the perceived red fruit aroma. In 2008 the addition of water to wine only decreased the perceived intensities of red fruit aromas, while the addition of water to the must only increased these perceptions (Table 6c). However, it must be remembered
TABLE $6 b$ (CONTINUED).

Significant sensory taste and mouthfeel attributes for 2007 wines made from grapes harvested at different levels of ${ }^{\circ}$ Brix and chaptalised and/or fortified or watered back. The values are the actual unstandardised means.

\begin{tabular}{|c|c|c|c|c|c|c|}
\hline & Sweet & Sour & Bitter & Astringent & Hot & Viscous \\
\hline H1NN & 1.3 & 5.1 & 2.4 & 4.2 & 2.3 & 2.5 \\
\hline H1NA & 1.4 & 5.1 & 2.2 & 4.0 & 2.6 & 2.6 \\
\hline H1BN & 1.4 & 5.3 & 2.5 & 4.1 & 2.4 & 2.7 \\
\hline H1BA & 1.4 & 5.0 & 2.6 & 4.2 & 2.5 & 2.9 \\
\hline $\mathrm{H} 2 \mathrm{NN}$ & 1.8 & 4.0 & 2.6 & 3.7 & 2.7 & 3.1 \\
\hline $\mathrm{H} 2 \mathrm{NA}$ & 2.0 & 4.2 & 2.4 & 3.8 & 2.7 & 3.1 \\
\hline $\mathrm{H} 2 \mathrm{BN}$ & 2.0 & 4.2 & 2.2 & 3.7 & 2.6 & 3.2 \\
\hline $\mathrm{H} 2 \mathrm{BA}$ & 1.8 & 4.3 & 2.3 & 3.5 & 2.5 & 3.1 \\
\hline $\mathrm{H} 3 \mathrm{NN}$ & 2.2 & 3.6 & 2.7 & 3.8 & 2.9 & 3.1 \\
\hline H3NA & 2.1 & 3.9 & 2.6 & 3.7 & 3.0 & 3.2 \\
\hline $\mathrm{H} 3 \mathrm{BN}$ & 1.9 & 3.8 & 2.8 & 3.8 & 2.9 & 2.9 \\
\hline H3BA & 2.0 & 3.6 & 3.1 & 3.6 & 2.9 & 3.2 \\
\hline H4NN & 2.6 & 3.2 & 3.0 & 3.7 & 3.3 & 3.3 \\
\hline H4NA & 2.2 & 3.2 & 2.7 & 3.4 & 2.8 & 3.0 \\
\hline H4BN & 2.2 & 3.7 & 2.5 & 3.4 & 3.1 & 3.1 \\
\hline H4BA & 2.0 & 3.4 & 2.5 & 3.4 & 2.8 & 3.0 \\
\hline $\mathrm{H} 5 \mathrm{NN}$ & 2.2 & 3.6 & 3.1 & 3.4 & 3.4 & 3.3 \\
\hline H5NA & 2.1 & 3.3 & 2.6 & 3.2 & 2.8 & 2.9 \\
\hline H5BN & 2.3 & 3.7 & 2.8 & 3.5 & 3.3 & 3.0 \\
\hline H5BA & 2.0 & 3.4 & 2.5 & 3.3 & 2.8 & 3.2 \\
\hline H6NN & 4.8 & 3.0 & 3.0 & 3.7 & 4.2 & 4.2 \\
\hline H6NA & 3.9 & 2.8 & 2.5 & 3.3 & 2.6 & 3.9 \\
\hline H6BN & 3.0 & 3.4 & 3.6 & 4.0 & 4.4 & 3.3 \\
\hline H6BA & 3.1 & 2.8 & 2.6 & 3.6 & 2.6 & 3.5 \\
\hline 1sd & 0.03 & 0.04 & 0.04 & 0.03 & 0.03 & 0.03 \\
\hline
\end{tabular}

that the $2008 \mathrm{H} 5$ had already been watered to $30^{\circ} \mathrm{Brix}$ from $36.6^{\circ}$ Brix prior to fermentation, and that all treatments were performed on the $30^{\circ}$ Brix must.

\section{Harvest 6}

In 2006, the addition of water before fermentation dramatically decreased the perceived sweetness of the resultant wines (Table 6a). The decrease in perceived hotness and viscosity of these wines was less, although still significant, while the increase in perceived sourness was quite substantial and the increase in bitterness was smaller but significant. In 2007 the addition of water before and after fermentation decreased perceived sweetness, with the larger effects occurring when the water addition occurred prior to fermentation (Table 6b). In 2007, sourness and bitterness increased most when water was only added to must prior to fermentation. In 2007, perceived bitterness decreased when 
TABLE 6c

Significant sensory aroma attributes for 2008 wines made from grapes harvested at different levels of ${ }^{\circ}$ Brix and chaptalised and/or fortified or watered back. The values are the actual unstandardised means.

\begin{tabular}{lcccc}
\hline & Red fruit & Fresh veg & Cooked veg & Spicy \\
\hline H2NN & 2.4 & 2.3 & 4.2 & 1.2 \\
H2NA & 2.1 & 2.6 & 3.3 & 1.4 \\
H2BN & 2.7 & 2.4 & 2.8 & 1.7 \\
H2BA & 2.4 & 2.7 & 3.0 & 1.3 \\
H3NN & 3.2 & 2.0 & 2.5 & 1.3 \\
H3NA & 2.6 & 1.8 & 2.4 & 1.1 \\
H3BN & 3.5 & 1.8 & 2.5 & 1.4 \\
H3BA & 3.1 & 2.2 & 1.9 & 1.5 \\
H4NN & 3.3 & 1.5 & 1.9 & 1.6 \\
H4NA & 3.7 & 2.0 & 2.0 & 1.5 \\
H4BN & 3.4 & 1.6 & 2.0 & 1.2 \\
H4BA & 3.0 & 2.0 & 1.9 & 1.5 \\
H5NN & 3.4 & 1.7 & 1.6 & 2.2 \\
H5NA & 3.0 & 1.7 & 1.7 & 1.7 \\
H5BN & 3.8 & 1.6 & 1.1 & 1.7 \\
H5BA & 3.4 & 1.8 & 1.6 & 1.3 \\
1sd & 0.60 & 0.52 & 0.59 & 0.43 \\
\hline
\end{tabular}

TABLE 6c (CONTINUED).

Significant sensory taste and mouthfeel attributes for 2008 wines made from grapes harvested at different levels of ${ }^{\circ}$ Brix and chaptalised and/or fortified or watered back. The values are the actual unstandardised means.

\begin{tabular}{lccccc}
\hline & Sweet & Sour & Bitter & Astringent & Hot \\
\hline H2NN & 1.0 & 4.0 & 3.1 & 2.9 & 2.1 \\
H2NA & 1.1 & 3.5 & 3.5 & 3.6 & 3.0 \\
H2BN & 1.2 & 4.2 & 2.8 & 3.4 & 2.4 \\
H2BA & 1.1 & 3.9 & 3.3 & 3.6 & 2.9 \\
H3NN & 1.3 & 3.9 & 3.5 & 3.3 & 2.5 \\
H3NA & 1.3 & 3.5 & 3.0 & 3.3 & 3.0 \\
H3BN & 1.4 & 3.9 & 3.1 & 3.5 & 2.9 \\
H3BA & 1.5 & 3.8 & 3.0 & 3.2 & 2.6 \\
H4NN & 1.5 & 4.1 & 3.2 & 3.7 & 3.4 \\
H4NA & 1.6 & 3.6 & 3.2 & 2.8 & 2.8 \\
H4BN & 1.7 & 3.8 & 3.2 & 3.3 & 2.9 \\
H4BA & 2.0 & 3.5 & 3.0 & 3.2 & 3.1 \\
H5NN & 2.2 & 3.2 & 4.7 & 3.8 & 5.4 \\
H5NA & 1.5 & 2.3 & 3.0 & 2.8 & 2.1 \\
H5BN & 1.8 & 3.5 & 4.2 & 4.0 & 4.2 \\
H5BA & 1.3 & 3.0 & 3.6 & 3.3 & 2.8 \\
1sd & 0.38 & 0.53 & 0.44 & 0.49 & 0.49 \\
\hline
\end{tabular}

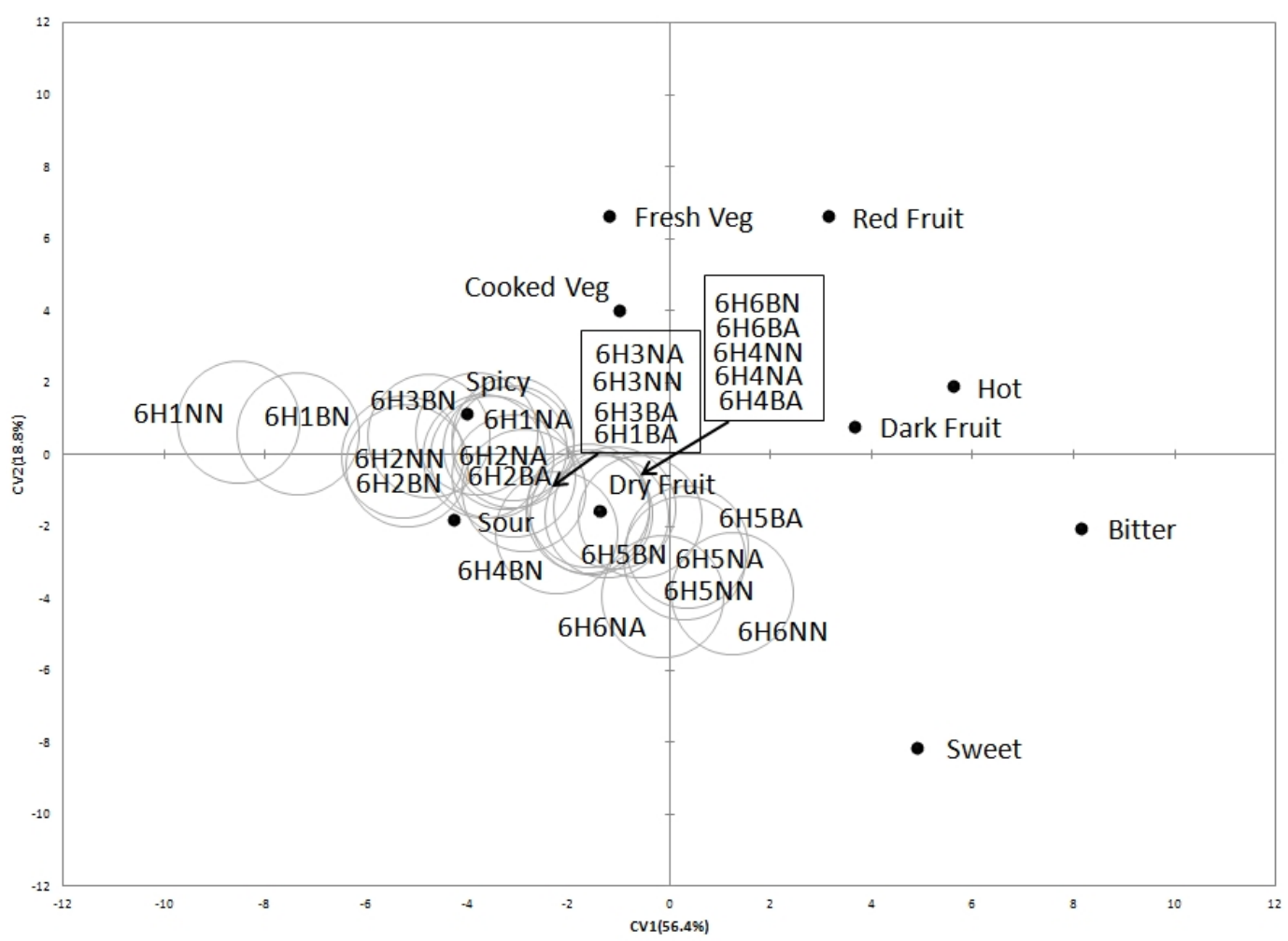

FIGURE 2a

Canonical variate analysis (CVA) for the sensory descriptive data by harvest for 2006. The CV scores for each harvest's wines are enclosed by a $95 \%$ ellipse. ${ }^{\circ}$ Brix at $\mathrm{H} 1$ averaged $22.4 ;{ }^{\circ}$ Brix at $\mathrm{H} 2$ averaged $23.1 ;{ }^{\circ}$ Brix at $\mathrm{H} 3$ averaged $24.7 ;{ }^{\circ} \mathrm{Brix}$ at $\mathrm{H} 4$ averaged 26.0; ${ }^{\circ}$ Brix at $\mathrm{H} 5$ averaged 27.8 and ${ }^{\circ}$ Brix at $\mathrm{H} 6$ averaged 30.7. $\mathrm{NN}$ - no additions, BN - only additions prior to fermentation, NA - only additions post-fermentation, BA - additions both pre- and post-fermentation. 


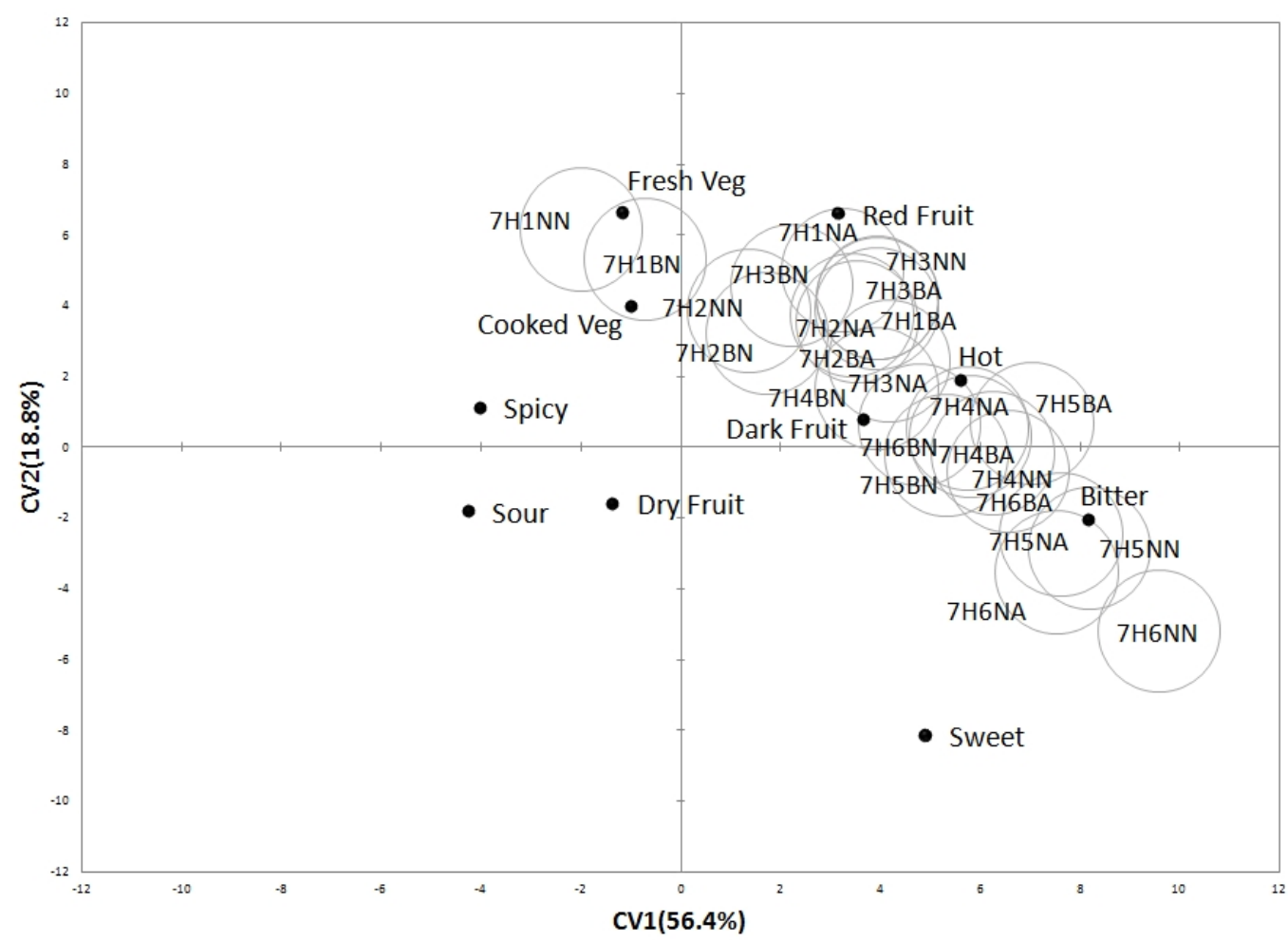

FIGURE $2 b$

Canonical variate analysis (CVA) for the sensory descriptive data by harvest for 2007. The CV scores for each harvest's wines are enclosed by a $95 \%$ ellipse. ${ }^{\circ}$ Brix at $\mathrm{H} 1$ averaged 21.0; ${ }^{\circ}$ Brix at $\mathrm{H} 2$ averaged 22.1; ${ }^{\circ}$ Brix at $\mathrm{H} 3$ averaged 24.6 ; ${ }^{\circ}$ Brix at $\mathrm{H} 4$ averaged 26.2; ${ }^{\circ}$ Brix at $\mathrm{H} 5$ averaged 26.2; and ${ }^{\circ}$ Brix at $\mathrm{H} 6$ averaged 30.8. $\mathrm{NN}$ - no additions, $\mathrm{BN}$ - only additions prior to fermentation, NA - only additions post-fermentation, BA - additions both pre- and post-fermentation.

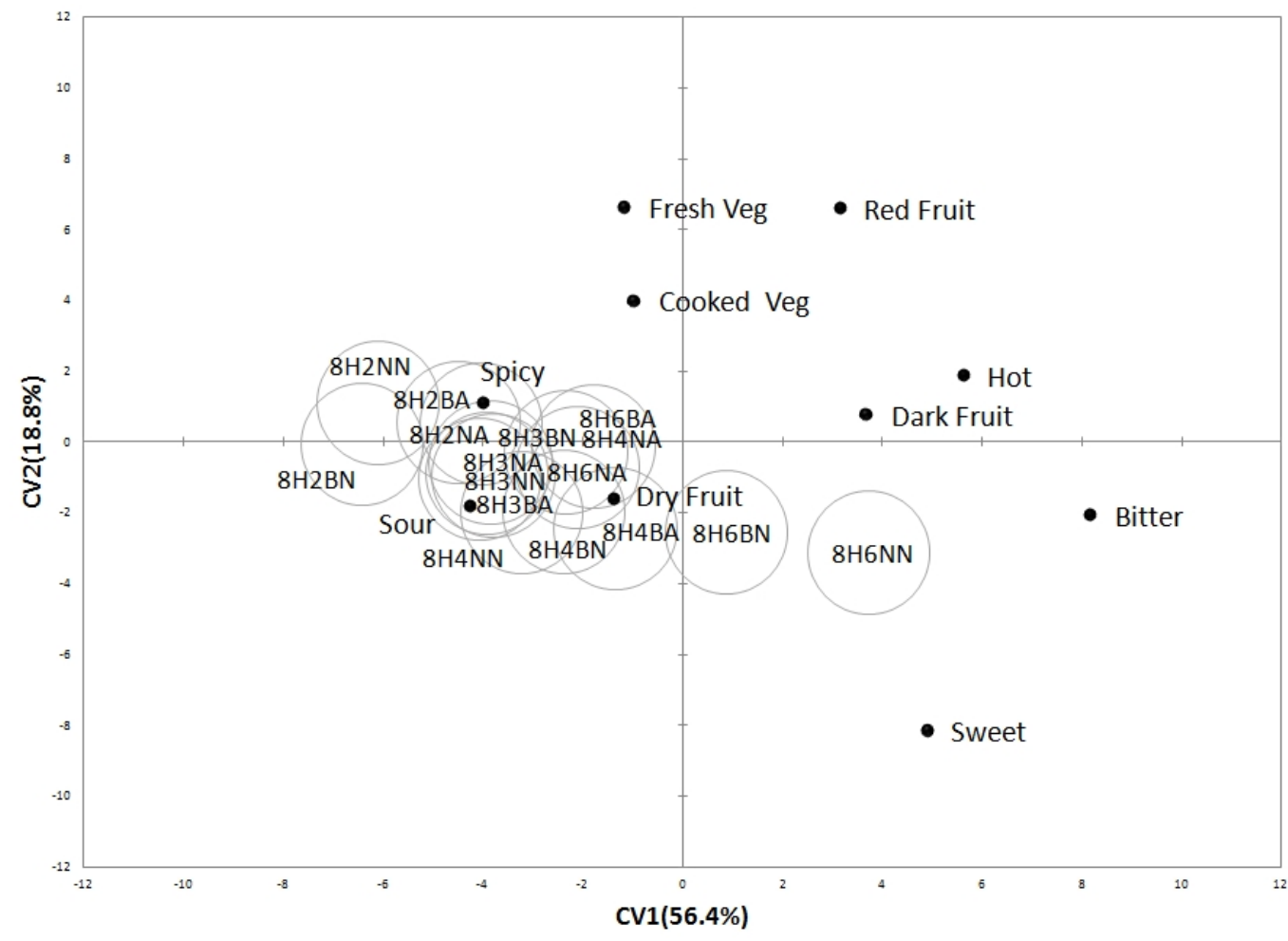

FIGURE 2c

Canonical variate analysis (CVA) for the sensory descriptive data by harvest for 2008. The CV scores for each harvest's wines are enclosed by a $95 \%$ ellipse. ${ }^{\circ}$ Brix at $\mathrm{H} 2$ averaged 22.6 ; ${ }^{\circ}$ Brix at $\mathrm{H} 3$ averaged 23.2 ; ${ }^{\circ}$ Brix at $\mathrm{H} 4$ averaged 25.0 and ${ }^{\circ}$ Brix at $\mathrm{H} 5$ averaged 36.6. $\mathrm{NN}$ - no additions, $\mathrm{BN}$ - only additions prior to fermentation, NA - only additions post-fermentation, $\mathrm{BA}-$ additions both pre- and post-fermentation. 
water was added to wines after fermentation. Astringency, hotness and viscosity decreased with water addition prior to and/or post-fermentation.

The CVA combining the 2006, 2007 and 2008 wines explained nearly $75 \%$ of the variance ratio in the first two dimensions. Again, to improve clarity we plotted the wines from each vintage in a separate figure - although these all overlie each other in the original plot. Ten of the sensory attributes (red fruit, dark fruit, fresh veg, cooked veg, dry fruit, spicy, sour, sweet, bitter and hotness) significantly discriminated between the wines across harvests and across sugar manipulation before and/or after fermentation. Figs $2 \mathrm{a}, 2 \mathrm{~b}$ and $2 \mathrm{c}$ show the two-dimensional plot for CV1 and CV2 for the 2006, 2007 and 2008 wines respectively. In all the years, chaptalisation before fermentation did not significantly affect the position of the wine on the CVA plot (see H1NN and H1BN for 2006 and 2007 and H2NN and $\mathrm{H} 2 \mathrm{BN}$ for 2008); conversely, fortifying the wines after fermentation significantly moved the wines towards similar areas as wines made from grapes with higher initial ${ }^{\circ} \mathrm{Brix}$ levels (see H1NA and H1BA for 2006 and 2007, as well as H2NA and H2BA for 2008). The adulteration of the musts and wines made from grapes harvested in the middle ${ }^{\circ}$ Brix ranges had very little effect on the final wines, as can be seen from the overlap of the treated wines on the CVA plots (see, for example, H3NN, H3NA, H3BN and H3BA for 2006). However, wines made from grapes with higher ${ }^{\circ}$ Brix levels were clearly affected by the addition of water. In 2006 and 2007, the wines made without water addition (H6NN) and the wines made with water addition after fermentation only (H6NA) did not differ, while the wines made with water addition before fermentation $(\mathrm{H} 6 \mathrm{BN})$ and with additional water after fermentation (H6BA) occupied similar positions on the CVA as wines made from grapes harvested at medium ${ }^{\circ}$ Brix levels. The exception was the last harvest in 2008, with the wines made from desiccated grapes harvested at $36.6{ }^{\circ}$ Brix that had been watered back to $30{ }^{\circ}$ Brix before fermentation. The H5NN was significantly different from all the other wines and the H5BN differed from the other two H5 wines.

Diluting musts at higher Brix to mimic the musts of grapes picked at $24{ }^{\circ}$ Brix resulted in wines that were similar to wines from grapes picked at about $24{ }^{\circ}$ Brix. This implies that there were few developmental changes in fruit composition of sensory importance late in maturation. These results are in agreement with those of Chaney et al. (2006) in relation to Chardonnay, but not in relation to Shiraz.

Fortifying wines from early harvests moved sensory attributes towards those of later harvests more than did sugar additions before fermentation. This result suggests that, while increasing final alcohol concentration, sugar additions are less effective than expected in mimicking fruit maturity, perhaps due to the sensory effects of adding alcohol besides the direct effect on the increase in alcohol concentration. It might be that alcohol interacts with fruit- or yeast-derived compounds in a sensorially significant way and thus our results differ from those of Gawel and co-workers (2007), while they are similar to the Shiraz results of Chaney et al. (2006), but not to their Chardonnay results.

\section{CONCLUSION}

In conclusion, harvesting Cabernet Sauvignon grapes at higher ${ }^{\circ}$ Brix levels leads to wines with less perceived sourness and fresh vegetative flavours, but with higher perceived levels of bitterness, hotness and, in some cases, dark fruit flavours and sweetness. There clearly is an optimum in terms of these flavours that would seem to be at about 25 to $26^{\circ}$ Brix. Fortifying wines made from musts with lower ${ }^{\circ}$ Brix changed perceptions of the wine sensory profiles more than did chaptalising the musts. These results are merely of academic interest, since both these practices would be illegal in California. Manipulating the sugar content of higher ${ }^{\circ}$ Brix musts by the addition of water to mimic $24{ }^{\circ}$ Brix musts results in wines with similar sensory profiles to wines made from grapes picked at the lower sugar content. This study shows that changes in fruit composition are more significant for wine sensory attributes early in ripening than after 24 ${ }^{\circ}$ Brix.

\section{LITERATURE CITED}

Amerine, M.A., 1953. The composition of wines. Scientific Monthly 77, 250-254.

Berg, H.W. \& Ough, C.S., 1977. Relation of degrees Balling to wine quality. Am. J. Enol. Vitic. 28, 235-238.

Brasser, S.M., Norman, M.B. \& Lemon, C.H., 2010. T1R3 taste receptor involvement in gustatory neural responses to ethanol and oral ethanol preference. Phys. Gen. 41, 232-243.

Callao, M.P., Borras, J.M, Lopez, A. \& Rius, F.X., 1991. Influence of the state of ripeness of Chardonnay grapes on wine composition. I. Physicochemical characteristics, higher alcohols, polyols and esters. Acta Alim. Budapest 20, 47-54.

Chaney, D., Rodriguez, S., Fugelsang, K. \& Thornton, R., 2006. Managing high-density commercial scale wine fermentations. J. Appl. Micro. 100, 689-698.

Chapman, D.M., Thorngate, J.H., Matthews, M.A., Guinard, J.-X. \& Ebeler, S.E., 2004a. Yield effects on 2-methoxy-3-isobutylpyrazine concentration on Cabernet Sauvignon using a solid phase micro-extraction gas chromatography/mass spectrometry method. J. Agric. Food Chem. 52, 5431-5435.

Chapman, D.M., Matthews, M.A. \& Guinard, J.-X., 2004b. Sensory attributes of Cabernet Sauvignon wines made from vines with different crop yields. Am. J. Enol. Vitic. 55, 325-334.

Chatfield, C. \& Collins, A.J., 1980. Introduction to multivariate analysis. Chapman and Hall, London.

Chikkasubbanna, V., Chadha, K.L. \& Ethiraj, S.S., 1990. Influence of maturity of Thompson Seedless grape on the wine composition and quality. Indian J. Hort. 47, 12-17.

Cooke, G.M., 1969. Varietal table wine processing practices in California. I. Varieties, grape and juice handling and fermentation. Am. J. Enol. Vitic. 20, 1-15.

Coombe, B.G., Dundon, R.J. \& Short, A.W.S., 1980. Indexes of sugaracidity as ripeness criteria for wine grapes. J. Sci. Food Agric. 31, 495-512.

Cortell, J.M., Sivertsen, H.K., Kennedy, J.A. \& Heymann, H., 2008. Influence of vine vigor on Pinot noir fruit composition, wine chemical analysis, and wine sensory attributes. Am. J. Enol. Vitic. 59, 1-10.

Dubois, C., Manginot, C., Roustan, J.L., Sablayrolles, J. M. \& Barre, P., 1996. Effect of variety, year, and grape maturity on the kinetics of alcoholic fermentation. Am. J. Enol. Vitic. 47, 363-368. 
Dukes, B.C. \& Butzke, C.E., 1998. Rapid determination of primary amino acids in grape juice using an o-phthaldialdehyde/N-acetyl-L-cysteine spectrophotometric assay. Am. J. Enol. Vitic. 49,125-134.

Du Plessis, C.S. \& Van Rooyen, P.C., 1982. Grape maturity and wine quality. S. Afr. J. Enol. Vitic. 3, 41-45.

Ewart, A.J.W., Brien, C.J., Soderlund, R. \& Smart, R.E., 1985. The effects of light pruning, irrigation and improved soil management on wine quality of the Vitis vinifera cv. Riesling. Vitis 24, 209- 217.

Fang, Y. \& Qian, M., 2006. Quantification of selected aroma-active compounds in Pinot noir wines from different grape maturities. J. Agric. Food Chem. 54, 8567-8573.

Gallander, J.F., 1983. Effect of grape maturity on the composition and quality of Ohio Vidal blanc grapes. Am. J. Enol. Vitic. 34, 139-141.

Gawel, R., Sluyter, S.V. \& Waters, E.J., 2007. The effects of ethanol and glycerol on the body and other sensory characteristics of Riesling wines. Aust. J. Grape Wine Res. 13, 38-45.

Hirsch, J., 2005. Winemakers, Growers Fight Over 'Hang Time'. Los Angeles Times. January 10, 2005.

Hjelmeland, A.K., King, E.S., Heymann, H. \& Ebeler, S.E., 2012 Characterizing the chemical and sensory profiles of US Cabernet Sauvignon wines. Am. J. Enol. Vitic. in press (doi: 10.5344/ajev.2012.12107).

Holt, H., Birchmore, W., Herderich, M. \& Iland, P.G., 2010. Berry phenolics in Cabernet sauvignon (Vitis vinifera $\mathrm{L}$ ) during late stage ripening. Am. J. Enol. Vitic. 61, 285-299.

King, E.S., Dunn, R.L. \& Heymann, H., 2013. The influence of alcohol on the sensory perception of red wines. Food Qual. Preference 28, 235-243.

Lawless, H.T. \& Heymann, H., 2010 ( $2^{\text {nd }}$ ed). Sensory evaluation of foods: principles and practices. Springer, New York.

Marais, J., 1987. Terpene concentrations and wine quality of Vitis vinifera L cv Gewurztraminer as affected by grape maturity and cellar practices. Vitis $26,231-245$.

Marais, J., Van Wyk, C. J. \& Rapp, A., 1992. Effect of sunlight and shade on norisoprenoid levels in maturing Weisser Riesling and Chenin Blanc grapes and Weisser Riesling wines S. Afr. J. Enol. Vitic. 13, 23-31.

Moreno, J.J., Cerpa-Calderon, F., Cohen, S.D., Fand, Y., Qian. M. \& Kennedy, J.A., 2008. Effect of postharvest dehydration on the composition of pinot noir grapes (Vitis vinifera L.) and wine. Food Chem. 109, 755-762.

Murovets, V.O., Zolotarev, V.A., Margolskee, R.F. \& Bachmanov, A.A., 2009. Taste receptor T1R3 is involved in detection of ethanol flavor in mice. Chem. Senses 34, A41-A41.

Naes, T. \& Langsrud, Ø., 1998. Fixed or random assessors in sensory profiling? Food Qual. Preference 9, 145-152.

Obreque-Slier, E., Pena-Neira, A., Lopez-Solis, R., Zamora-Marin, F., Ricardo-Silva, J.M. \& Laureano, O., 2010. Comparative study of the phenolic composition of seeds and skins from Carmenere and Cabernet sauvignon grape varieties (Vitis vinifera L.) during ripening. J. Agric. Food Chem. 8, 3591-3599.
Ough, C.S. \& Singleton, V.S., 1968. Wine quality prediction from juice Brix/acid ratio and associated compositional changes for 'White Riesling' and 'Cabernet Sauvignon'. Am. J. Enol. Vitic. 19, 129-138.

Peynaud, E., 1978. Criteria of quality wines. Ann. Tech. Agricolae 27, $337-$ 347.

Pineau, B., Trought, M.C.T., Stronge, K., Beresford, M.K. \& Jaeger, S.R., 2011. Influence of fruit ripeness and wine ethanol concentration on the sensory properties and degree of typicality expressed by Sauvignon blanc wines from Marlborough, New Zealand. Aust.. J. Grape Wine Res. 17, 358 367 .

Preston, L.D., Block, D.E., Heymann, H., Soleas, G., Noble, A.C. \& Ebeler, S.E., 2008. Defining vegetal aromas in Cabernet Sauvignon using sensory and chemical evaluations. Am. J. Enol. Vitic. 59, 137-145.

Reynolds, A.G., Wardle, D.A. \& Dever, M., 1996a. Vine performance, fruit composition, and wine sensory attributes of Gewürztraminer in response to vineyard location and canopy manipulation. Am. J. Enol. Vitic. 47, 77-92.

Reynolds, A.G., Yerle, S., Watson, B., Price, S.F. \& Wardle, D.A., 1996b. Fruit environment and crop level effects on Pinot noir. III. Composition and descriptive analysis of Oregon and British Columbia wines. Am. J. Enol. Vitic. 47, 329-339.

Ristic, R., Downey, M.O., Iland, P.G., Bindon, K., Francis, I.L., Herderich, M. \& Robinson, S.P., 2007. Exclusion of sunlight from Shiraz grapes alters wine colour, tannin and sensory properties. Aust. J. Grape Wine Res. 13, 53-65.

Rolle, L., Rio Segade, S., Torchio, F., Giacosa, S., Cagnasso, E., Marengo, F. \& Gerbi, V., 2011. Influence of grape density and harvest date on changes in phenolic composition, phenol extractability indices, and instrumental properties during ripening. J. Agric. Food Chem. 59, 8796-8805.

Schmidt, J.O. \& Noble, A.C., 1983. Investigation of the effect of skin contact time on wine flavor. Am. J. Enol. Vitic. 34, 135-138.

Scinska, A., Koros, E., Habrat, B., Kukwa, A., Kostowski, W. \& Bienkowski, P., 2000. Bitter and sweet components of ethanol taste in humans. Drug Alcohol Depend. 60, 199-206.

Sharma, K.D., Sharma, P.C. \& Lal, B.B., 1997. Effect of fruit maturity on yield, composition and quality of juice and wine from grapes. J. Sci. Ind. Res. 56, 627-632

Suresh, E.R. \& Ethiraj, S., 1987. Effect of grape maturity on the composition and quality of wines made in India. Am. J. Enol. Vitic. 38, 329-331.

Torchio, F., Cagnasso, E., Gerbi, V. \& Rolle, L., 2010. Mechanical properties, phenolic composition and extractability indices of Barbera grapes of different soluble solids contents from several growing areas. Anal. Chim. Acta 660, 183-189.

Zamora, M.C., Goldner, M.C. \& Galmarini, M.V., 2006. Sournesssweetness interactions in different media: white wine, ethanol and water. J. Sens. Stud. 21, 601-611. 